\title{
Geochemistry and Nd-Sr Isotopic Signatures of the Pensamiento Granitoid Complex, Rondonian-San Ignacio Province, Eastern Precambrian Shield of Bolivia: Petrogenetic Constraints for a Mesoproterozoic Magmatic Arc Setting \\ Geoquímica e Assinaturas Nd-Sr do Complexo Granitoide Pensamiento, Província Rondoniana-San Ignacio, Pré-Cambriano de Bolívia O riental: Caracterização Petrogenética de um Arco Magmático no Mesoproterozoico
}

\author{
Ramiro Matos ${ }^{1,3}$ (rmatoss@igc.usp.br), Wilson Teixeira1(wteixeir@usp.br), \\ Mauro Cesar Geraldes² (geraldes@uerj.br), Jorge Silva Bettencourt¹ (jsbetten@usp.br) \\ ${ }^{1}$ Departamento de Mineralogia e G eotectônica - Instituto de G eociências - USP \\ R. do Lago 562, CEP 05508-080, São Paulo, SP, BR \\ ${ }^{2}$ Faculdade de Geologia - UERJ, Rio de Janeiro, RJ, BR \\ ${ }^{3}$ Instituto de Investigaciones G eológicas y del Medio Ambiente - UMSA, La Paz, BO
}

Recebido em 04 de dezembro de 2008; aceito em 15 de maio de 2009

\begin{abstract}
The Pensamiento Granitoid Complex (PGC), located in the northern part of the eastern Precambrian shield of Bolivia, is tectonically assigned to the Rondonian-San Ignacio Province (1.55 - 1.30 Ga) of the Amazonian Craton that is made up by Archean and Proterozoic provinces. The Proterozoic ones result from accretionary orogens that become successively younger southwestwards, such as the Rondonian/San Ignacio (1.37 - $1.32 \mathrm{Ga})$ and the Sunsás orogenies $(1.20$ - 1.00 Ga). The PGC crops out mainly on the "Paragua craton" bounded to the south by the Sunsás belt, and composed of granites and subvolcanic terms, and subordinately of syenites, granodiorites, tonalites, trondhjemites and diorites as orogenic representatives of the Rondonian/San Ignacio Orogeny, intrusive into the Lomas Maneches (ca. 1.68 Ga) and Chiquitania (ca. 1.7 Ga) complexes. Thirteen whole rock chemical analyses for major, trace and REE elements were performed for the La Junta, San Martín, Diamantina, Porvernir, San Cristobal, Piso Firme plutons of the PGC. The negative trends of $\mathrm{MgO}, \mathrm{Al}_{2} \mathrm{O}_{3}$ and $\mathrm{CaO}$ contents with increasing $\mathrm{SiO}_{2}$ suggest that fractional crystallization played an important role in the petrogenesis of the investigated rocks. The data also indicate a mainly peraluminous, sub-alkaline to high-K calc-alkaline composition, and fractionated LREE/ HREE patterns are consistent with a magmatic arc character for these plutons. SHRIMP U-Pb zircon ages of the La Junta and San Martín syn- to late-kinematic plutons are $1347 \pm 21$ Ma and $1373 \pm 20$ Ma respectively, and the Sm-Nd $\mathrm{T}_{\mathrm{DM}}$ model ages are between 1.9 to $2.0 \mathrm{Ga}$, while $\varepsilon_{\mathrm{Nd}(1330)}$ values range from +1.8 to -4.3 , respectively. In addition, the late- to post-kinematic Diamantina pluton yields SHRIMP U-Pb zircon age of $1340 \pm 20 \mathrm{Ma}$, and variable $\mathrm{Sm}-\mathrm{Nd} \mathrm{T}_{\mathrm{DM}}$ model ages (1.6 to $\left.1.9 \mathrm{Ga}\right)$ and $\varepsilon_{\mathrm{Nd}(1330)}$ values (+0.4 to -1.2) that are comparable with previous results found for other coeval plutons. The Porvenir, San Cristobal and Piso Firme plutons show $\varepsilon_{\mathrm{Nd}(1330)}$ signatures varying from +1.5 to +2.7 , in agreement with a plutonic arc setting as is suggested for the Diamantina pluton. Integrated interpretation of the geochemical and isotopic data coupled with new geologic correlations of the PGC with contemporary units in the Brazilian counterpart establishes one Mesoproterozoic magmatic arc in the evolution of the Rondonian-San Ignacio province.
\end{abstract}

Keywords: Bolivia; Pensamiento Granitoid Complex; Geochemistry; Nd-Sr isotopes; Rondonian-San Ignacio province; Amazonian Craton.

\section{RESUMO}

O Complexo Granitoide Pensamiento (CGP) ocorre na porção norte do Pré-Cambriano Boliviano, estando tectonicamente associado à evolução da província Rondoniana-San Ignacio (1.55 - 1.30 Ga) do Craton Amazônico, constituído por uma província central de idade arqueana e províncias proterozoicas marginais. A evolução proterozoica resulta do desen- 
volvimento de cinturões acrescionários sucessivamente mais jovens para sudoeste, a exemplo das orogenias Rondoniana-San Ignacio (1.37 - $1.32 \mathrm{Ga})$ e Sunsás (1.20 - $1.00 \mathrm{Ga})$. O CGP ocorre na parte setentrional do Pré-Cambriano Boliviano, ao norte do cinturão Sunsás, sendo constituído por granitos e termos subvulcânicos. Subordinadamente ocorrem sienitos, granodioritos, tonalitos, trondjemitos e dioritos. Em termos tectônicos, essas rochas são classificadas em dois conjuntos: plutons sin a tardicinemáticos e tardi a pós-cinemáticos. Treze análises químicas em rocha total para elementos maiores, traços e ETR foram realizadas em rochas granitoides orogênicas do CGP. Diagramas de correlação geoquímica indicam tendência negativa entre os conteúdos de $\mathrm{MgO}, \mathrm{Al}_{2} \mathrm{O}_{3}$ and $\mathrm{CaO}$ em função do aumento de $\mathrm{SiO}_{2}$, sugerindo processos de cristalização fracionada na petrogênese das rochas investigadas. Em adição os dados indicam uma composição principalmente peraluminosa, subalcalina de alto K, compatível com ambiente de arco magmático, para a geração dos plútons estudados, corroborado pelo padrão de fracionamento dos ETRL/ETRP. Datações SHRIMP em zircão dos plútons La Junta e San Martín (sin a tardicinemáticos; $1347 \pm 21$ e $1373 \pm 20$ Ma, respectivamente) em conjunto com idades modelo $\mathrm{T}_{\mathrm{DM}}$ entre 1,9 e 2,0 Ga e valores de $\varepsilon_{\mathrm{Nd}(1330)}$ entre $+1,8$ e $-4,3$ são semelhantes a resultados publicados em outros corpos coevos. Em adição, os plútons Porvenir, San Cristobal e Piso Firme (tardi a pós-cinemáticos) têm idades $\mathrm{T}_{\mathrm{DM}}$ modelo entre 1,6 e 1,7 Ga e valores de $\varepsilon_{\mathrm{Nd}(1330)}$ positivos entre $+2,7$ e $+1,5$, o que sugere uma origem em arco magmático intraoceânico. O plúton Diamantina (tardi a pós-cinemático; idade SHRIMP em zircão de $1340 \pm 20 \mathrm{Ma}$ ) tem idades $\mathrm{T}_{\mathrm{DM}}$ modelo entre 1,6 e 1,9 Ga com valores de $\varepsilon_{\mathrm{Nd}(1330)}$ entre $+0,4$ e $-1,2$. Isto corrobora a hipótese de significativa contribuição de material juvenil mesoproterozoico durante a sua gênese. Os resultados aqui obtidos interpretados em conjunto com os dados geológicos de unidades contemporâneas na contraparte brasileira reforçam a existência de um arco magmático juvenil mesoproterozoico que finalizou a evolução acrescionária da província Rondoniana-San Ignacio.

Palavras-chave: Bolívia; Complexo Granitoide Pensamiento; Província Rondoniana-San Ignacio; Geoquímica; Isótopos Nd-Sr.

\section{INTRODUCTION}

The Pensamiento Granitoid Complex (PGC) constitutes a large volume of Mesoproterozoic gneisses and granitoid rocks that occur in the Bolivian departments of Santa Cruz and Beni. The PGC rocks are one of the major components that built up the Rondonian-San Ignacio Province (1.55 to $1.30 \mathrm{Ga}$; e.g., Cordani and Teixeira, 2007) of widespread extension along the SW part of the Amazonian Craton, Brazil (Rondônia and Mato Grosso states besides Bolivia). Tectonically the PGC (Figures 1 and 2) is attributed to the onset of the San Ignacio orogeny in Bolivia (1400 - $1280 \mathrm{Ga}$; Litherland et al., 1986), as part of the "Paraguá Craton" which bounds are subjected to Sunsás-age low grade metamorphic and shearing overprints (e.g., Litherland et al., 1989; Boger et al., 2005). The San Ignacio orogeny produced three fold generations overprinting Paraguá crystalline basement rocks, whereas the earliest stages of deformation established the observed metamorphic sequence at regional scale (Litherland et al., 1986, 1989; Boger et al., 2005). Field mapping of the PGC revealed that the plutonic rocks are syn- to late-kinematic with reference to Do3 deformational event (Litherland and Bloomfield, 1981) whilst the late- to postkinematic ones crosscut Do3.

We have carried out a reconnaissance geologic investigation along the road that connects Santa Rosa de la Roca and Piso Firme localities (Figure 2), covering a $330 \mathrm{~km}$ transverse along the PGC. From south to north, the studied units are: the syn- to late-kinematic La Junta and San Martín granites, and the late- to post-kinematic Diamantina, Porvenir and San Cristobal granites and the Piso Firme granophyre. However, further detailed geological studies are needed to better define the relationships among the granitoid rocks and with the crystalline basement. The present work is part of an ongoing $\mathrm{PhD}$ project (R. Matos) at the Institute of Geosciences of University of São Paulo, Brazil, aiming to delineate the petrogenetic evolution of the PGC and its tectonic significance. We present petrographic and geochemical data coupled with systematic Sr-Nd isotopic work of PGC rocks, supported by SHRIMP published and unpublished data. The integrated interpretation provides new insights on the nature the Granitoid Complex with implications for the Mesoproterozoic history of the SW part of the Amazonian Craton.

\section{GEOLOGIC FRAMEWORK}

The Rondonian-San Ignacio Province - RSIP (Figure 1) was formed by Mesoproterozoic accretionary belts whose dynamics included stacking of intra-oceanic and continental arcs, as well as intervening microcontinents. The accretionary/agglutination processes culminated with collision against the already cratonized Rio Negro-Juruena Province $(1.78$ - $1.55 \mathrm{Ga})$, in the southwest part of the Amazonian Craton. Lithologically the RSIP consists predominantly of granite-gneiss and granitoid rocks, some of them with rapakivi structures, as well as tonalites and granulites. Isotopic studies on these rocks indicate positive to slightly negative $\varepsilon_{\mathrm{Nd}(t)}$ signatures, roughly between +4.0 and -2.0 , reinforcing the idea that juvenile events combined with reworking of the pre-existent crust played a major role during the long-lived plate convergence and collision against the tectonically stable foreland (see for review Tassinari et al., 2000; Cordani and Teixeira, 2007). 


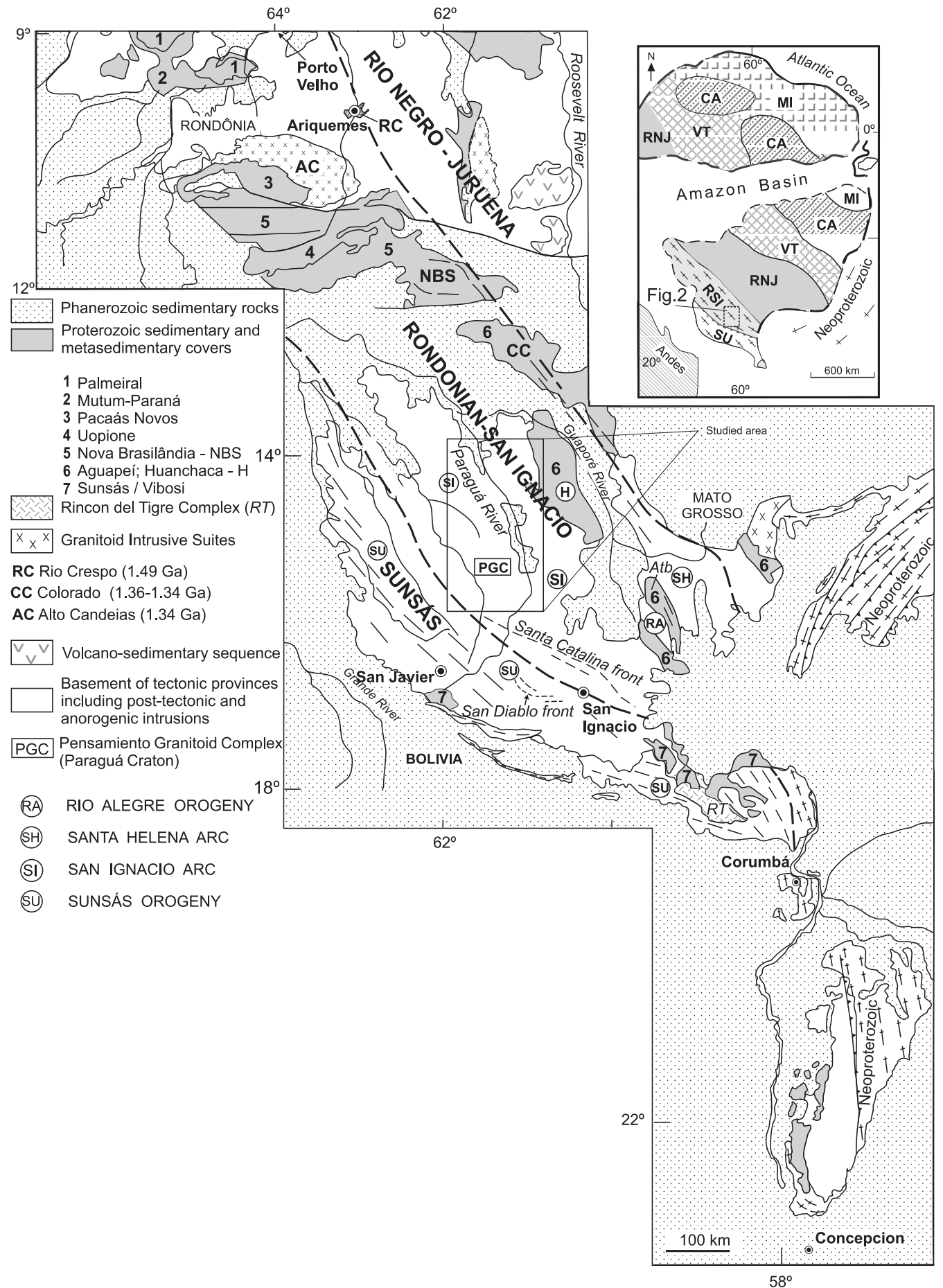

Figure 1. Geologic outline of the SW portion of the Amazonian Craton showing the main orogenic belts, the tectonically related intrusive magmatic suites and sedimentary covers and volcano-sedimentary sequences. The inferred boundaries between the Proterozoic provinces are also shown (adapted from Cordani and Teixeira, 2007). Keys: SP = Serra da Providência batholith, CMS = Colorado Metamorphic Sequence; NBS = Nova Brasilândia Sequence. Inset: geochronological provinces of the Amazonian Craton = Central Amazonian - CA (> 2.6 Ga); Maroni-Itacaiúnas - MI (2.25 - 2.05 Ga); Ventuari-Tapajós - VT (1.98 - 1.81 G a); Rio Negro-Juruena - RNJ (1.78 - 1.55 Ga); Rondonian-San Ignacio - RSI (1.55 - $1.30 \mathrm{Ga}$ ) and Sunsás - SU (1.25 - $0.97 \mathrm{Ga})$. See text for details. 


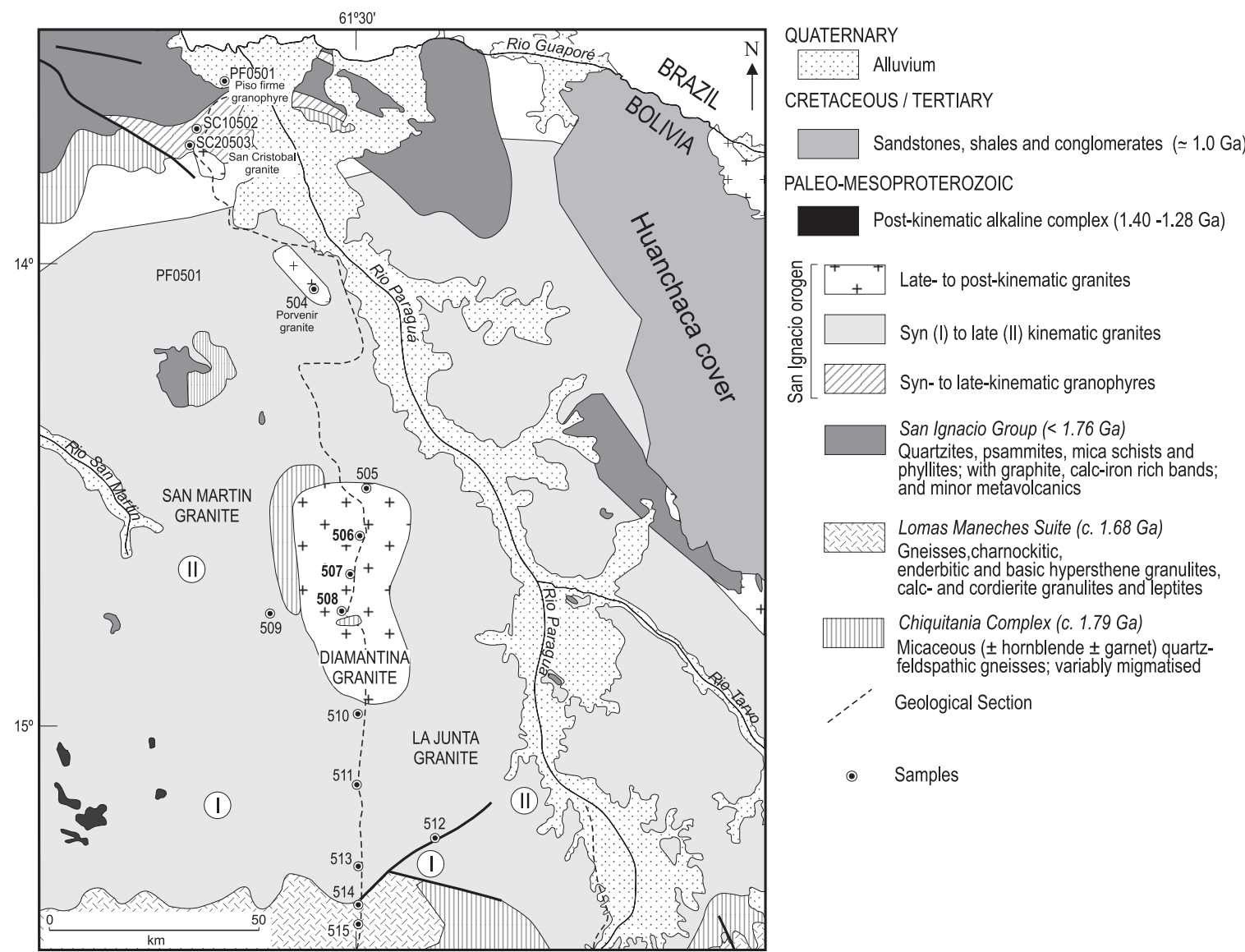

Figure 2. Geologic sketch of the studied area showing the regional occurrence of the Pensamiento Granitoid Complex (PG C) and the country rocks (modified from Litherland et al., 1986).

The collision features between the Rio Negro-Juruena and Rondonian-San Ignacio provinces are mirrored by faults, shear zones and fold-and-thrust belts (e.g., Tassinari et al., 2000), and associated to granulitic facies metamorphism $(1.35-1.32 \mathrm{Ga})$ that overprint the country rocks in some places of the state of Rondônia, Brazil (SHRIMP U/Pb ages of zircon overgrowths; Bettencourt et al., 1999; Payolla et al., 2002; Santos et al., 2005) - see Table 1 and Figure 1. Contemporarily, the Colorado Complex (1.35 Ga), a "mafic" to "chemical"-clastic assemblage of passive-margin setting of the RSIP, in Rondônia (e.g., Teixeira et al., 2006), was deformed and overprinted by recognized medium- to high grade metamorphism. During this phase syn- to late tectonic, high-K, calc-alkaline granitoid rocks (e.g., Igarapé Enganado and Alto Escondido suites; 1345 - $1336 \mathrm{Ma}$ ) were emplaced into the Colorado Complex (Rizzotto and Quadros, 2007), whereas coeval granitoid rocks intruded into the already cratonized Rio Negro-Juruena crust (e.g., Alto Candeias Intrusive Suite; $1.34 \mathrm{Ga}$ ) - see Figure 1. On the whole all of these magmatic and metamorphic events are representative of the Rondonian-San Ignacio orogeny of widespread occurrence in the SW corner of the Amazonian Craton (Cordani and Teixeira, 2007; Teixeira and Cordani, 2009).

The RSIP exhibits a polycyclic evolution, giving rise to several rock units (e.g., Rio Crespo, Santa Helena, Rio Alegre, Colorado, PCG; see Table 2) that show chemical and isotopic affinities of island arc and continental arc settings. These rock units were variably overprinted by the Sunsás orogeny $(1.2-1.0 \mathrm{Ga})$ at the same time that several coeval geologic features were formed in Rondônia and Bolivia, such as rift basins (e.g., Nova Brasilândia, Pacaás Novos, Palmeiral), platform covers (e.g., Huanchaca/Aguapeí; see Figure 2), shear zones and basic and felsic magmatism (Rizzotto et al., 2002; Litherland et al., 1986; Tohver et al., 2006). The emplacement of the Santa Bárbara and Santa Clara Intrusive Suites between 1.08 and $0.98 \mathrm{Ga}$ and of the Younger Granites of Rondônia $(0.99$ - $0.97 \mathrm{Ga})$ reveals the important role of extensional regimes over the cratonized crust during post-tectonic or anorogenic stages of the Sun- 
Table 1. Main characteristics of the Rondonian-San Ignacio and Sunsás provinces, SW Amazonian Craton. Keys: RSI = Rondonian-San Ignacio orogeny; SU = Sunsás orogeny.

\begin{tabular}{|c|c|c|c|}
\hline Characteristics of the Province & Major events & $\begin{array}{l}\text { Main regional units and } \\
\text { crustal structures }\end{array}$ & $\begin{array}{c}\text { Main intrusive } \\
\text { complexes }\end{array}$ \\
\hline $\begin{array}{l}\text { Rondonian-San Ignacio (RSI) } \\
(1.55-1.30 \mathrm{Ga}) \text {. }\end{array}$ & $\begin{array}{l}\text { - Rio Crespo Intrusive Suite } \\
(1.49 \mathrm{Ga}) \text {. } \\
\text { - Rio Alegre orogen: island arc }\end{array}$ & $\begin{array}{l}\text { Ocean floor mafic-ultramafic } \\
\text { rocks. } \\
\text { Calc-alkaline rocks. }\end{array}$ & $\begin{array}{l}\text { Late to post-tectonic } \\
\text { intrusions: e.g., Alto } \\
\text { Candeias }(1.34 \mathrm{Ga})\end{array}$ \\
\hline $\begin{array}{l}\text { Collisional orogeny combined with } \\
\text { accretionary domains. } \\
\text { Voluminous orogenic plutonism. }\end{array}$ & $\begin{array}{l}\text { affinity rocks }(1.51-1.48 \mathrm{Ga} \\
\left.\varepsilon_{\mathrm{Ndt}} \text { from }+2.5 \text { to }+4.7\right) \\
\text { - Santa Helena arc (calc } \\
\text { alkaline granitoid rocks). }\end{array}$ & $\begin{array}{l}\text { MCG associations: bimodal } \\
\text { magmatism (1.36-1.35 Ga). } \\
\text { San Ignacio orogenic granitoids }\end{array}$ & $\begin{array}{l}\text { Santa Clara } \\
(1.08-1.07 \mathrm{Ga}) \text { and } \\
\text { Santa Bárbara } \\
(1.08-0.98 \mathrm{Ga})\end{array}$ \\
\hline Regional cooling (1.31 - $1.30 \mathrm{Ga})$. & $\begin{array}{l}\left(1.44-1.42 \mathrm{Ga} ; \varepsilon_{\mathrm{Ndt}} \text { from }+2.6\right. \\
\text { to }+4.0)\end{array}$ & $\begin{array}{l}(1.34-1.32 \mathrm{Ga}) \\
\text { Rift basins tectonically linked }\end{array}$ & granitoid Suites. \\
\hline $\begin{array}{l}\text { Foreland for the Sunsás orogeny } \\
\text { with contemporary tectonic } \\
\text { reactivations and magmatism. }\end{array}$ & $\begin{array}{l}\text { - RSI orogeny: a) Colorado } \\
\text { Complex metamafic and } \\
\text { chemical-clastic assemblage } \\
\text { metamorphosed to medium to } \\
\text { high-grade facies }(1.36-1.32 \\
\left.\text { Ga; } \varepsilon_{\text {Ndt }} \text { from }+0 \text { to }+5.2\right) ; \text { b) } \\
\text { Pensamiento Granitoid } \\
\text { Complex, San Ignacio orogeny } \\
\text { (PGC; } 1.32-1.37 \mathrm{Ga}) \text {. }\end{array}$ & $\begin{array}{l}\text { with the Sunsás orogeny (see } \\
\text { below): Pacaas Novos, } \\
\text { Uopione, Palmeiral, } \\
\text { Aguapeí/Huanchaca, } \\
\text { Sunsás/Vibosi, sedimentary } \\
\text { deposits. }\end{array}$ & $\begin{array}{l}\text { Anorogenic plutonism: } \\
\text { e.g., Younger Granites } \\
\text { of Rondônia } \\
(0.99-0.97 \mathrm{Ga}) \text {. }\end{array}$ \\
\hline Sunsás (SU) (1.20 - 1.00 Ga). & $\begin{array}{l}\text { - Deformation and } \\
\text { metamorphism: thrust and shear }\end{array}$ & $\begin{array}{l}\text { Passive margin assemblages } \\
\text { overprinted by regional }\end{array}$ & $\begin{array}{l}\text { Post-tectonic plutonism: } \\
(0.97-0.92 \mathrm{Ga}) \text {. }\end{array}$ \\
\hline $\begin{array}{l}\text { Collisional orogeny with thrust } \\
\text { and fold belts. }\end{array}$ & $\begin{array}{l}\text { belts }(1.10 \mathrm{Ga}) \text {. } \\
\text { - Local thermal overprint due to }\end{array}$ & $\begin{array}{l}\text { deformation and metamorphism. } \\
\text { Syn- to late orogenic plutonism. }\end{array}$ & $\begin{array}{l}\text { Rincón del Tigre mafic- } \\
\text { ultramafic complex }\end{array}$ \\
\hline $\begin{array}{l}\text { Cratonization and regional } \\
\text { exhumation of the SW Amazonian } \\
\text { Craton }(1.00-0.92 \mathrm{Ga})\end{array}$ & granite emplacement. & $\begin{array}{l}\text { Nova Brasilândia Sequence } \\
(1.21-1.05 \mathrm{Ga}) \text { : bimodal } \\
\text { magmatism and sediments. }\end{array}$ & $(\sim 1.0 \mathrm{Ga})$ \\
\hline
\end{tabular}

sás orogeny (e.g., Bettencourt et al., 1999; Payolla et al., 2002; Sparrenberger et al., 2002).

Litherland and Bloomfield (1981) originally defined the Sunsás orogeny as a cycle of sedimentation that took place in an extensional environment (e.g., Sunsás and Vibosi groups; Litherland et al., 1989). This was followed by erosion, deformation and metamorphism of the passive-margin sedimentary sequences, as well as of the PGC and the crystalline basement rocks named Paraguá Craton. Due to the Sunsás orogeny, brittle cataclastic deformation and mylonitization largely overprinted the country rocks giving rise to Rio Negro Front, the Santa Catalina Zone (Litherland et al., 1986; Klinck and O'Connor, 1983; Litherland and Klinck, 1982), the Blanco-Ibaiminí Line Shear Zone and the curvilinear San Diablo Front, in Bolivia (Figure 1). In addition, coeval reactivated structures over the RSIP developed northward (e.g., Aguapeí fold and thrust belt, Nova Brasilândia belt, in Brazil - Figure 2). As such, the boundary between the Rio Negro-Juruena and Sunsás provinces with the RSIP is a very complex one.
The RSIP has been studied by several authors by means of geologic mapping, structure, geochemistry, geochronology (e.g., Litherland et al., 1986; Teixeira et al., 1989; Sato and Tassinari, 1997; Bettencourt et al., 1999; Cordani et al., 2000; Tassinari et al., 2000; Geraldes et al., 2001; Payolla et al. 2002; Boger et al., 2005; Santos et al., 2006, 2008). These efforts have also led to paleotectonic reconstructions mainly using geologic correlations, paleomagnetism and age data from the granitoid systems and mafic magmatism (Sadowski and Bettencourt, 1996; Tassinari et al., 2000; Tohver et al., 2002, 2004a, 2004b, 2005a, 2005b). Table 2 presents SHRIMP U-Pb, Rb-Sr and K-Ar ages of selected geologic units of the Bolivian Precambrian shield, including the data available for the PGC rocks to be discussed afterward.

The geologic framework of Bolivian Precambrian Shield (Litherland et al., 1986, 1989) comprises mainly four lithostratigraphic units based on the geologic work performed by the British Geologic Survey - GEOBOL, supported by $\mathrm{Rb} / \mathrm{Sr}$ and K/Ar ages: 1. the Lomas Maneches Granulitic Complex; 2. the Chiquitania Gneissic Complex; 3. the San 
Ignacio Schist Group; 4. the PGC - see Table 2 and Figure 2. The Lomas Maneches Complex was originally considered as the oldest lithoestratigraphic unit of the shield, as suggested by $\mathrm{Rb} / \mathrm{Sr}$ regional model age, but this assumption have been discarded on the basis of more precise SHRIMP work recently reported (see below). It comprises bands of charnockitic, enderbitic, and basic hypersthene granulites, and gneisses that contain metamorphic hypersthene or cordierite. The Chiquitania Gneiss Complex, considered to be structurally over the Granulite Complex, consists of banded micaceous quartz-feldspathic gneisses, without hypersthene and/ or cordierite. These rocks in the "Paraguá craton" show K-Ar mineral ages in the range $1.34-1.32 \mathrm{Ga}$ that compare well with the age pattern of the granitoid rocks of the PGC (assigned as the San Ignacio orogeny). The San Ignacio Schist Group crops out as discrete NW belts that are surrounded by distinct gneisses and granitoid rocks of the Lomas Maneches and Chiquitania units. It is composed of quartzites, metapsamites, schists, phyllites and metavolcanics. This unit is overlaid by the flat-lying sediments of the Sunsás Group (e.g., Huanchaca Formation) in the "Paraguá craton" (Figures 1 and 2).

Subsequently Boger et al. (2005) performed additional geologic work with the add of SHRIMP U-Pb zircon geochronology in distinct rock units that crop out southward from the PGC (see Figure 2), thereby providing new

Table 2. Summary of SHRIMP U-Pb, Rb-Sr and K-Ar ages of selected rocks of Bolivian Precambrian shield. Keys: zr $=$ zir$\mathrm{con} ; \mathrm{hb}=$ hornblende; $\mathrm{bi}=$ biotite; $w r=$ whole rock isochron; Met. age = metamorphic age; Inh. age = inherited age; * K-Ar cooling age; ** Isochron model age (spurious); ${ }^{P}$ Pensamiento G ranitoid Complex. References: a. Boger et al. (2005); b. Santos et al. (2006; 2008); c. Litherland et al. (1986).

\begin{tabular}{|c|c|c|c|c|c|c|c|c|}
\hline Unit & Rock & Sample & $\begin{array}{l}\text { Age } \\
(\mathrm{Ma})\end{array}$ & $\begin{array}{c}\text { Met. age } \\
\text { (Ma) }\end{array}$ & $\begin{array}{c}\text { Inh. age } \\
\text { (Ma) }\end{array}$ & Method & Mat. & Ref. \\
\hline Chiquitania & gneiss & $235 \mathrm{~A} 1$ & & $1333 \pm 6$ & & $\mathrm{U}-\mathrm{Pb}$ & $\mathrm{zr}$ & $a$ \\
\hline Chiquitania & gneiss & $235 \mathrm{~A}$ & $1764 \pm 12$ & & & $\mathrm{U}-\mathrm{Pb}$ & $\mathrm{zr}$ & a \\
\hline Chiquitania & gneiss & 23 & $1336 \pm 33^{*}$ & & & $\mathrm{~K}-\mathrm{Ar}$ & $\mathrm{hb}$ & c \\
\hline Chiquitania & gneiss & 24 & $1323 \pm 33^{*}$ & & & $\mathrm{~K}-\mathrm{Ar}$ & $\mathrm{hb}$ & c \\
\hline Lomas Maneches & gneiss & 240 & $1663 \pm 13$ & $1320 \pm 11$ & & $\mathrm{U}-\mathrm{Pb}$ & $z r$ & $b$ \\
\hline Lomas Maneches & granulite & - & $\sim 1960^{\star *}$ & & & $\mathrm{Rb}-\mathrm{Sr}$ & $w r$ & c \\
\hline Lomas Maneches & gneiss & JO5 & & $1334 \pm 2$ & & $\mathrm{U}-\mathrm{Pb}$ & $\mathrm{zr}$ & $b$ \\
\hline Lomas Maneches & granulite & JO3 & $1818 \pm 13$ & $1339 \pm 4^{\star *}$ & & $\mathrm{U}-\mathrm{Pb}$ & $\mathrm{zr} ;{ }^{* *} \mathrm{mo}$ & $b$ \\
\hline Lomas Maneches & gneiss & 261 & $1689 \pm 5$ & & & $\mathrm{U}-\mathrm{Pb}$ & $\mathrm{zr}$ & a \\
\hline Refugio & granite & JO12 & $1641 \pm 4$ & & $1668 \pm 8$ & $\mathrm{U}-\mathrm{Pb}$ & $\mathrm{zr}$ & $b$ \\
\hline San Ramón & granite & JO14 & $1429 \pm 4$ & & & $\mathrm{U}-\mathrm{Pb}$ & $z r-t i$ & $b$ \\
\hline San Rafael & granite & 228 & $1334 \pm 12$ & & $1686 \pm 16$ & $\mathrm{U}-\mathrm{Pb}$ & $\mathrm{zr}$ & a \\
\hline Santa Rita & orthogneiss & JO18 & $1319 \pm 6$ & & $1746 \pm 21$ & $\mathrm{U}-\mathrm{Pb}$ & $\mathrm{zr}$ & $b$ \\
\hline Rio Fortuna & orthogneiss & JO6 & $1336 \pm 3$ & & $1753 \pm 10$ & $\mathrm{U}-\mathrm{Pb}$ & $\mathrm{zr}$ & $b$ \\
\hline San Ignacio & paragneiss & 221D & $<1764 \pm 6$ & & & U-Pb & $\mathrm{zr}$ & a \\
\hline San Ignacio & schist & - & 1340 & & & $\mathrm{Rb}-\mathrm{Sr}$ & $w r$ & c \\
\hline Florida $^{P}$ & granite & 151 & $1244 \pm 27^{*}$ & & & $\mathrm{~K}-\mathrm{Ar}$ & bi & c \\
\hline Florida $^{P}$ & granite & 189 & $1380 \pm 19$ & & & $\mathrm{~K}-\mathrm{Ar}$ & bi & c \\
\hline Padre Eterno ${ }^{P}$ & granite & 178 & $1326 \pm 19^{*}$ & & & $\mathrm{~K}-\mathrm{Ar}$ & bi & c \\
\hline Piso Firme ${ }^{P}$ & granophyre & - & $1325 \pm 45$ & & & $\mathrm{Rb}-\mathrm{Sr}$ & $w r$ & c \\
\hline La Junta ${ }^{P}$ & granite & - & $1375 \pm 80$ & & & $\mathrm{Rb}-\mathrm{Sr}$ & $w r$ & c \\
\hline Diamantina $^{P}$ & granite & - & $1391 \pm 70$ & & & $\mathrm{Rb}-\mathrm{Sr}$ & $w r$ & c \\
\hline San Andrés & granite & JO10 & $1275 \pm 7$ & & & U-Pb & $\mathrm{zr}$ & $b$ \\
\hline Orobayaya & granite & - & $1283 \pm 33$ & & & $\mathrm{Rb}-\mathrm{Sr}$ & $w r$ & $\mathrm{c}$ \\
\hline E Tigre & alkaline & - & $1286 \pm 46$ & & & $\mathrm{Rb}-\mathrm{Sr}$ & $w r$ & c \\
\hline San Javier & granite & - & $1291 \pm 49$ & & & $\mathrm{Rb}-\mathrm{Sr}$ & $w r$ & $\mathrm{C}$ \\
\hline San Cristobal & granite & 153 & $1296^{\star} \pm 18$ & & & $\mathrm{~K}-\mathrm{Ar}$ & bi & c \\
\hline Cerro Grande & granophyre & - & $1176 \pm 100$ & & & $\mathrm{Rb}-\mathrm{Sr}$ & $w r$ & c \\
\hline
\end{tabular}


insights on the chronostratigraphy of Bolivian Precambrian shield. They interpreted the Lomas Maneches as a magmatic suite consisting of granitic sills that were emplaced after the deposition of the Chiquitania Complex, but previously to the deposition of the San Ignacio Group. The main results (Table 2) are summarized as follow:

1. one sample from the Lomas Maneches suite contains zircon core that yielded a weighted mean ${ }^{207} \mathrm{~Pb} /{ }^{206} \mathrm{~Pb}$ age of $1663 \pm 13 \mathrm{Ma}$, inferred as the rock's emplacement age. Additional analyses of the zircon rims yielded an age of $1320 \pm 11 \mathrm{Ma}$, interpreted as the time of partial melting;

2. another Lomas Maneches sample yielded a concordant ${ }^{207} \mathrm{~Pb} /{ }^{206} \mathrm{~Pb}$ zircon age of $1689 \pm 5 \mathrm{Ma}$;

3. two samples of the Chiquitania Complex showed zircon cores with inherited ages of $1788 \pm 16 \mathrm{Ma}, 1757 \pm$ $14 \mathrm{Ma}$ and $1764 \pm 12 \mathrm{Ma}$, whilst the zircon rims were interpreted as metamorphic $(1333 \pm 6 \mathrm{Ma})$;

4. one San Ignacio paragneiss yielded (29 detrital zircons) a concordant ${ }^{207} \mathrm{~Pb} /{ }^{206} \mathrm{~Pb}$ age of $1764 \pm 6 \mathrm{Ma}$;

5. five zircon cores from the syn-kinematic San Rafael Granite yielded an upper intercept age of $1686 \pm 16 \mathrm{Ma}$, suggesting its derivation from a Paleo- to Mesoproterozoic protolith - an idea that was already envisaged by the limited $\mathrm{Nd}$ isotopic evidence reported for selected PGC rocks (Darbyshire, 2000). Finally, the San Rafael pluton has zircon rim analyses that yielded an upper intercept ${ }^{207} \mathrm{~Pb} /{ }^{206} \mathrm{~Pb}$ age of $1334 \pm 12 \mathrm{Ma}$, indicating the tectonic relationship with the San Ignacio orogeny.

Santos et al. $(2006,2008)$ reported additional SHRIMP $\mathrm{U}-\mathrm{Pb}$ ages in zircon, monazite and titanite from granitoid rocks to the south of PGC. One sample of the Lomas Maneches granulitic gneiss has magmatic zircons with ${ }^{207} \mathrm{~Pb} /{ }^{206} \mathrm{~Pb}$ age of $1818 \pm 13 \mathrm{Ma}$, which is the oldest age identified in Bolivia up to present. The monazite from this rock gives a metamorphic age of $1342 \pm 3 \mathrm{Ma}$, in agreement with the age of another Lomas Maneches sample that has metamorphic zircons with $1334 \pm 2.4 \mathrm{Ma}$ (concordant ${ }^{207} \mathrm{~Pb} /{ }^{206} \mathrm{~Pb}$ age). On the other hand the Refugio granite has zircons with no metamorphic rim, and yields a ${ }^{207} \mathrm{~Pb} /{ }^{206} \mathrm{~Pb}$ age of $1641 \pm 4 \mathrm{Ma}$ and $\mathrm{T}_{\mathrm{DM}}$ model age of $1.7 \mathrm{Ga}\left(\varepsilon_{\mathrm{Nd}(\mathrm{t})}=\right.$ $+4.06)$. The San Ramon granite yields similar zircon and titanite ${ }^{207} \mathrm{~Pb} /{ }^{206} \mathrm{~Pb}$ ages of $1429 \pm 4 \mathrm{Ma}$. Its $\mathrm{Sm}-\mathrm{Nd} \mathrm{T}_{\mathrm{DM}}$ model age is $1.6 \mathrm{Ga}\left(\varepsilon_{\mathrm{Ndt}}=+2.3\right)$. Therefore both granites were mainly derived from Mesoproterozoic juvenile sources. The San Andrés granite yields a ${ }^{207} \mathrm{~Pb} /{ }^{206} \mathrm{~Pb}$ age of $1275 \pm 7 \mathrm{Ma}$, and may represent one of the syn-kinematic granites associated to Sunsás orogeny. On the other hand, the Rio Fortuna orthogneiss has two zircon populations: the first population (inherited core grains) between 1772 - 1734 Ma whereas the second one (magmatic zircon and rims) formed at $1336 \pm 3$ Ma. Finally, the Santa Rita orthogneiss has magmatic zircons with ${ }^{207} \mathrm{~Pb} /{ }^{206} \mathrm{~Pb}$ age of $1319 \pm 6 \mathrm{Ma}$, although a single grain yields an inherited $\mathrm{U}-\mathrm{Pb}$ age of $1729 \pm 9 \mathrm{Ma}$ (see Table 2).

In summary, the U-Pb SHRIMP ages and Sm-Nd data, coupled with the more recent field information of the Precambrian rocks of Eastern Bolivia established the age and igneous nature of the Lomas Maneches suite (1.69 $1.66 \mathrm{Ga})$. Furthermore the U-Pb data evidenced some significantly older protholiths (up to $1.82 \mathrm{Ga}$ ) may have participated in the Proterozoic evolution. On the other hand, the San Ignacio orogeny, marked by syn- to late- kinematic plutonic pulses (PGC) and coeval metamorphism, took place in Bolivian territory between $1.37-1.32 \mathrm{Ga}$. This time interval correlates well with the ultimate tectonic and magmatic episodes assigned to the Rondonian-San Ignacio orogeny in the Brazilian counterpart, as proposed by Cordani and Teixeira (2007) and Teixeira and Cordani (2009).

\section{The Pensamiento Granitoid Complex}

The PGC consists of voluminous intrusive plutonic and subvolcanic granitic rocks, with subordinate syenites, granodiorites, tonalites, trondhjemites and diorites, which have been dated firstly by $\mathrm{Rb} / \mathrm{Sr}$ and $\mathrm{K} / \mathrm{Ar}$ methods that indicate ages between 1.39 to $1.24 \mathrm{Ga}$ (Litherland et al., 1986) (see Table 2). According to these authors the youngest $\mathrm{K}$-Ar ages refer to the uplift and regional cooling of the Paraguá craton. In addition, they distinguished two intrusive magmatic events within the PGC, on the basis of the structural work: the syn- to late-kinematic and the late- to post-kinematic granitoid rocks such as the San Martín and La Junta granites, and the Diamantina pluton, respectively. Moreover, they recognized two regional metamorphic episodes (Mo1 and Mo2) in association with the San Ignacio Orogeny, attributed to the Do1/Do2 and Do3 deformational phases, respectively, whereas the metamorphism varies from low grade to granulite facies. A high grade hypersthene zone was recognized to the west of the San Martín river, and decreases to medium grade on the both sides of it (Klinck and O'Connor, 1983). The Do3, the major penetrative event in the area, accompanies generation of the bulk syn-kinematic granitoid plutons. Some of the late to post-kinematic granitoid plutons postdate Do3 phase and were emplaced following a markedly NNW trend (Litherland et al., 1986).

Recent geologic mapping (R. Mattos, pers. information) has revealed that the La Junta pluton has sharp intrusive contacts with the 1.69 - 1.66 Ga Lomas Maneches suite. Moreover, the field information has indicated that the San Cristóbal, Porvenir, and Diamantina granites, besides the Piso Firme granophyre (Figure 2), are late- to 
post- kinematic, although Litherland et al. (1986) classified this granophyre as a syn- to late- tectonic intrusion. Furthermore, in the Brazilian counterpart (southeastern of Rondônia), contemporary orogenic and post-orogenic granites are intrusive into the 1.36 - $1.30 \mathrm{Ga}$ Colorado Complex (Rizzotto and Quadros, 2007), that is tectonically linked with the Rondonian-San Ignacio Orogeny, as proposed by Teixeira and Cordani (2009).

The syn- to late- kinematic Puerto Alegre/La Junta granites of PGC display comparable $\mathrm{T}_{\mathrm{DM}}$ model ages $(2.0$ and $2.1 \mathrm{Ga})$ and $\varepsilon_{\mathrm{Nd}(\mathrm{T})}$ values of -1.5 and -2.8 , respectively (Darbyshire, 2000; Darbyshire, pers. comm., 2007). In contrast, the $\sim 1.35$ Ga Piso Firme granophyre (Litherland et al., 1986) yields significant younger but comparable $T_{D M}$ model ages $(1.5$ and $1.6 \mathrm{Ga})$ and positive $\varepsilon_{\mathrm{Nd}(\mathrm{T})}$ values $(+3.3$ to +3.9$)$. In a similar way the contemporary Diamantina and Orobayaya granites yield positive $\varepsilon_{\mathrm{Nd}(\mathrm{T})}$ values $(+1.0$ to +1.4 ) and $\mathrm{T}_{\mathrm{DM}}$ model ages of $1.7 \mathrm{Ga}$ (see Table 1 ).

\section{ANALYTICAL TECHNIQUES}

Thirteen samples were selected for major and minor elements $\left(\mathrm{SiO}_{2}, \mathrm{TiO}_{2}, \mathrm{Al}_{2} \mathrm{O}_{3}, \mathrm{Fe}_{2} \mathrm{O}_{3 \mathrm{Tot}}, \mathrm{MnO}, \mathrm{MgO}, \mathrm{CaO}\right.$, $\mathrm{K}_{2} \mathrm{O}, \mathrm{Na}_{2} \mathrm{O}$ and $\mathrm{P}_{2} \mathrm{O}_{5}$ ) and trace elements chemistry at Chemical Laboratory of Institute of Geosciences of the University of São Paulo (IGc/USP), Brazil (Table 3), and following the technical procedures for REE separation as reported by Navarro (2004). The samples were first powered to $<200$ mesh in an agate mill. The analytical routine for major elements and some trace elements comprises fusion using a mixture of $0.25 \mathrm{~g}$ of rock powder and $0.75 \mathrm{~g}$ flux (lithium tetra and metaborate). $\mathrm{HNO}_{3} 0.2 \mathrm{~N}$ solutions diluted to 1:1000 were analyzed in an ARL-3410 sequential spectrometer. The routine of the laboratory comprises: fluorescence X-ray spectrometry (Philips PW2400) for the analysis of the major and minor elements $\left(\mathrm{SiO}_{2}, \mathrm{TiO}_{2}\right.$, $\mathrm{Al}_{2} \mathrm{O}_{3}, \mathrm{FeO}_{\text {Tot }}, \mathrm{MnO}, \mathrm{MgO}, \mathrm{CaO}, \mathrm{K}_{2} \mathrm{O}, \mathrm{P}_{2} \mathrm{O}_{5}$ ); atomic absorption spectrometry, after dissolution with $\mathrm{HF}+\mathrm{HCLO}_{4}$ for $\mathrm{Na}_{2} \mathrm{O}$; decomposition with $\mathrm{HF}+\mathrm{H}_{2} \mathrm{SO}_{4}$ in platinum crucible buffered for $\mathrm{FeO}$, and $\mathrm{FeO}$ titullation with $\mathrm{KMnO}_{4}$; loss of ignition by calcination at $1000^{\circ} \mathrm{C}$ under constant weight; X-ray fluorescence spectrometry using pressed powder pellets for $\mathrm{Ba}, \mathrm{Rb}, \mathrm{Sr}, \mathrm{Zr}, \mathrm{Y}, \mathrm{Cu}, \mathrm{Pb}$ and $\mathrm{Zn}$.

The same thirteen samples were analyzed by $\mathrm{Sm}-\mathrm{Nd}$ whole-rock technique at the Geochronological Research Center (CPGeo) of the IGc-USP (Table 4). Approximately $0.1 \mathrm{mg}$ of powdered rock sample was dissolved in concentrated $\mathrm{HNO}_{3}$, $\mathrm{HF}$ and $\mathrm{HCl}$. The Sm and Nd concentrations were determined by isotope dilution with a combined spike tracer, using the two-column technique, as described by Sato et al. (1995). The isotope ratios were measured on VG-354 multi-collector mass spectrometer.
Laboratory blanks for the chemical procedure, during the period of analyses, yielded maximum values of $0.4 \mathrm{ng}$ for $\mathrm{Nd}$ and $0.7 \mathrm{ng}$ for Sm. The average ${ }^{143} \mathrm{Nd} /{ }^{144} \mathrm{Nd}$ for La Jolla standard was 0.511857 (46), with $2 \sigma$ standard deviations reported in parentheses. The $\mathrm{Sm}-\mathrm{Nd} \mathrm{T}_{\mathrm{DM}}$ model ages, were calculated using DePaolo (1981) model parameters: $\mathrm{a}=0.25, \mathrm{~b}=3, \mathrm{c}=8.5$ as well as ${ }^{143} \mathrm{Nd} /{ }^{144} \mathrm{Nd}=0.7219$ to normalize the isotope ratios $\left[{ }^{143} \mathrm{Nd} /{ }^{144} \mathrm{Nd}(\mathrm{CHUR})_{0}=\right.$ 0.512638 and $\left.{ }^{147} \mathrm{Sm} /{ }^{144} \mathrm{Nd}(\mathrm{CHUR})_{0}=0.1967\right]$. The $\varepsilon_{\mathrm{Nd}}$ values were calculated using the simplified equation $\varepsilon_{\mathrm{Nd}(\mathrm{T})}$ $=\varepsilon_{\mathrm{Nd}(0)}-\mathrm{Q}_{\mathrm{Nd}} \mathrm{f}_{\mathrm{Sm} / \mathrm{Nd}} \mathrm{T}$, with the (CHUR), values above and $\mathrm{Q}_{\mathrm{Nd}}=25.09$. The $\varepsilon_{\mathrm{Nd}}$ values for the PGC samples were recalculated for the 1.33 Ga reference age (SHRIMP U-Pb, as reported by Boger et al., 2005).

In addition to the Sm-Nd work, thirteen samples were analyzed by $\mathrm{Rb}-\mathrm{Sr}$ using isotope dilution technique at the CPGeo (Table 5). The ${ }^{87} \mathrm{Sr} /{ }^{86} \mathrm{Sr}$ ratios are listed with absolute errors $(2 \sigma)$, and have been corrected to the mean value of the NBS-987 standard $[0.710254 \pm 0.000022(2 \sigma)]$. The overall blank for the chemical procedure was $4 \mathrm{ng}$ for $\mathrm{Sr}$. Isotope ratios were measured on VG-354 multicollector and single collector mass spectrometers, and the ${ }^{87} \mathrm{Sr} /{ }^{86} \mathrm{Sr}$ ratios were normalized to ${ }^{86} \mathrm{Sr} /{ }^{88} \mathrm{Sr}=0.1194$.

\section{RESULTS}

The investigated samples were previously studied by petrography (see Appendix A). The new isotopic and geochemical data were interpreted together with the published characteristics of PGC rocks (e.g., Litherland et al., 1986; Darbyshire, 2000), and taking into account the geochronologic background of the Bolivian Precambrian shield, particularly SHRIMP U-Pb zircon ages of distinct rock-units of Paraguá craton (Boger et al., 2005; Santos et al., 2006, 2008), including the unpublished ones (data from R. Matos).

\section{Field aspects and petrography}

Appendix A presents hand sample and petrographic descriptions with modal composition, textures and structures of the investigated PCG rocks (see Figure 2) whereas Appendix B summarizes the megascopic and microscopic petrography of this PGC after Klinck and O'Connor (1983); Hawkins (1982); Pitfield (1983) and Litherland (1982).

Modal composition for selected rocks of the PGC was determined using macro point counting method as described by Fitch (1959). Staining of rock slabs was necessary to distinguish between $\mathrm{K}$-feldspar and plagioclase and to determine their proportions (Table 6). The investigated syn- to late-kinematic rocks can be classified mostly as syenogranites, monzogranites and quartz monzonites whe- 
Table 3. Major and trace elements of the PG C. Keys: Porv. = Porvenir; Diam.= Diamantina.

\begin{tabular}{|c|c|c|c|c|c|c|c|c|c|c|c|c|c|}
\hline Sample & $\begin{array}{c}\text { PF } \\
0501\end{array}$ & $\begin{array}{c}\text { SC } \\
10502\end{array}$ & $\begin{array}{c}\text { SC } \\
20503\end{array}$ & $\begin{array}{l}\text { PRV } \\
0504\end{array}$ & $\begin{array}{c}C P \\
0505\end{array}$ & $\begin{array}{c}C P \\
20506\end{array}$ & $\begin{array}{c}\text { CP } \\
30507\end{array}$ & $\begin{array}{c}\text { ME } \\
0508\end{array}$ & $\begin{array}{c}\text { CA } \\
0509\end{array}$ & $\begin{array}{l}\text { FLT } \\
0510\end{array}$ & $\begin{array}{c}\text { LJ } \\
10511\end{array}$ & $\begin{array}{c}\text { LJ } \\
20512\end{array}$ & $\begin{array}{c}\text { LJ } \\
30513\end{array}$ \\
\hline Unit & $\begin{array}{l}\text { Piso } \\
\text { Firme }\end{array}$ & $\begin{array}{c}\text { San } \\
\text { Cristobal }\end{array}$ & $\begin{array}{c}\text { San } \\
\text { Cristobal }\end{array}$ & & & & & & $\begin{array}{c}\text { San } \\
\text { Martín }\end{array}$ & $\begin{array}{c}\text { La } \\
\text { Junta }\end{array}$ & $\begin{array}{c}\text { La } \\
\text { Junta }\end{array}$ & $\begin{array}{l}\text { La } \\
\text { Junta }\end{array}$ & $\begin{array}{c}\text { La } \\
\text { Junta }\end{array}$ \\
\hline Rock & QSy & $\mathrm{MzGrBi}$ & $\mathrm{MzGrBi}$ & SyGrHb & SyGrBi & SyGrBi & SyGrBi & QMzBi & SyGrHb & SyGr & QMzBi & $\mathrm{MzGrBi}$ & $\mathrm{MzGrHb}$ \\
\hline $\mathrm{SiO}_{2}$ & 76.07 & 76.08 & 74.12 & 74.26 & 72.33 & 72.14 & 73.53 & 74.84 & 76.76 & 69.27 & 71.26 & 74.19 & 68.63 \\
\hline $\mathrm{Al}_{2} \mathrm{O}_{3}$ & 12.44 & 12.46 & 13.02 & 13.75 & 14.39 & 14.47 & 13.49 & 13.43 & 11.51 & 14.83 & 14.48 & 14.16 & 15.46 \\
\hline $\mathrm{MnO}$ & 0.025 & 0.030 & 0.054 & 0.043 & 0.035 & 0.034 & 0.034 & 0.033 & 0.044 & 0.034 & 0.032 & 0.022 & 0.030 \\
\hline $\mathrm{MgO}$ & 0.06 & 0.08 & 0.22 & 0.22 & 0.30 & 0.29 & 0.28 & 0.19 & 0.09 & 0.75 & 0.43 & 0.24 & 0.59 \\
\hline $\mathrm{CaO}$ & 0.56 & 0.56 & 1.07 & 1.27 & 1.33 & 1.28 & 1.15 & 1.00 & 0.62 & 1.24 & 1.33 & 2.04 & 1.80 \\
\hline $\mathrm{Na}_{2} \mathrm{O}$ & 4.47 & 3.73 & 3.49 & 3.74 & 3.19 & 3.21 & 2.96 & 3.36 & 2.41 & 2.55 & 2.80 & 3.63 & 3.49 \\
\hline $\mathrm{K}_{2} \mathrm{O}$ & 4.07 & 4.88 & 4.86 & 4.53 & 5.52 & 5.94 & 5.44 & 5.07 & 5.63 & 6.52 & 6.30 & 3.96 & 4.98 \\
\hline $\mathrm{TiO}_{2}$ & 0.123 & 0.117 & 0.242 & 0.173 & 0.255 & 0.243 & 0.241 & 0.140 & 0.188 & 0.477 & 0.330 & 0.106 & 0.442 \\
\hline $\mathrm{P}_{2} \mathrm{O}_{5}$ & 0.017 & 0.017 & 0.048 & 0.047 & 0.068 & 0.062 & 0.067 & 0.051 & 0.025 & 0.148 & 0.120 & 0.044 & 0.156 \\
\hline $\mathrm{Fe}_{2} \mathrm{O}_{3}$ & 1.50 & 1.42 & 2.24 & 1.31 & 1.68 & 1.65 & 2.03 & 1.35 & 2.20 & 2.79 & 2.05 & 1.33 & 3.24 \\
\hline Loi & 0.67 & 0.38 & 0.21 & 0.39 & 0.38 & 0.20 & 0.34 & 0.40 & $<0.01$ & 0.82 & 0.40 & 0.19 & 0.67 \\
\hline Total & 100.01 & 99.75 & 99.57 & 99.73 & 99.48 & 99.52 & 99.56 & 99.86 & 99.48 & 99.43 & 99.53 & 99.91 & 99.49 \\
\hline ACNK & 0.97 & 1.00 & 1.00 & 1.03 & 1.05 & 1.03 & 1.05 & 1.05 & 1.03 & 1.10 & 1.04 & 1.01 & 1.07 \\
\hline $\mathrm{K}_{2} \mathrm{O} / \mathrm{Na}_{2} \mathrm{O}$ & 0.91 & 1.31 & 1.39 & 1.21 & 1.73 & 1.85 & 1.84 & 1.51 & 2.34 & 2.56 & 2.25 & 1.09 & 1.43 \\
\hline $\mathrm{Ba}$ & 811 & 336 & 614 & 822 & 902 & 776 & 690 & 429 & 721 & 1515 & 776 & 805 & 525 \\
\hline $\mathrm{Nb}$ & 11 & 10 & 8 & 22 & 9 & 7 & 12 & 8 & 7 & 13 & 12 & 4 & 20 \\
\hline $\mathrm{Pb}$ & 6 & 13 & 12 & 21 & 44 & 39 & 44 & 55 & 22 & 26 & 40 & 20 & 36 \\
\hline $\mathrm{Rb}$ & 100 & 157 & 158 & 179 & 245 & 212 & 249 & 251 & 144 & 165 & 224 & 141 & 223 \\
\hline $\mathrm{Sr}$ & 24 & 24 & 59 & 21 & 215 & 201 & 153 & 176 & 69 & 287 & 168 & 296 & 109 \\
\hline Th & 8 & 7 & 6 & 14 & 20 & 39 & 55 & 32 & 17 & 20 & 33 & 5 & 67 \\
\hline$U$ & 3 & 3 & 2 & 5 & 5 & 7 & 8 & 16 & 1 & 2 & 3 & 2 & 5 \\
\hline V & $<9$ & $<9$ & $<9$ & $<9$ & $<9$ & 18 & 14 & $<9$ & $<9$ & 26 & 14 & 16 & 37 \\
\hline$Y$ & 45 & 66 & 54 & 148 & 23 & 18 & 18 & 122 & 95 & 54 & 23 & 7 & 43 \\
\hline $\mathrm{Zr}$ & 215 & 142 & 197 & 360 & 178 & 197 & 185 & 118 & 292 & 206 & 216 & 110 & 314 \\
\hline $\mathrm{La}$ & 31.4 & 33.0 & 34.8 & 65.1 & 69.7 & 99.5 & 70.0 & 24.2 & 91.6 & 64.0 & 70.5 & 17.2 & 110 \\
\hline $\mathrm{Ce}$ & 60.1 & 61.7 & 55.9 & 179 & 128 & 128 & 182 & 56.9 & 212 & 130 & 148 & 31.8 & 220 \\
\hline $\mathrm{Pr}$ & 7.83 & 8.97 & 9.45 & 19.3 & 15.2 & 21.3 & 17.8 & 6.49 & 26.8 & 20.2 & 17.3 & 3.55 & 25.9 \\
\hline $\mathrm{Nd}$ & 29.2 & 35.1 & 36.4 & 76.0 & 52.4 & 71.1 & 61.2 & 23.5 & 106 & 76.1 & 60.5 & 11.6 & 91.0 \\
\hline $\mathrm{Sm}$ & 6.44 & 8.13 & 8.33 & 17.9 & 8.55 & 11.0 & 11.2 & 5.95 & 24.1 & 14.0 & 10.8 & 1.77 & 16.3 \\
\hline $\mathrm{Eu}$ & 0.64 & 0.44 & 1.12 & 1.88 & 1.20 & 1.27 & 1.24 & 0.79 & 2.70 & 1.95 & 1.10 & 0.59 & 1.15 \\
\hline $\mathrm{Gd}$ & 6.61 & 8.59 & 8.30 & 20.1 & 7.34 & 9.21 & 9.28 & 7.96 & 24.3 & 12.5 & 9.81 & 1.75 & 15.6 \\
\hline $\mathrm{Tb}$ & 1.13 & 1.52 & 1.48 & 3.57 & 0.77 & 0.90 & 1.00 & 1.92 & 3.88 & 1.71 & 1.08 & 0.21 & 1.86 \\
\hline Dy & 7.10 & 9.36 & 8.98 & 22.3 & 3.75 & 4.06 & 4.45 & 14.1 & 21.0 & 9.39 & 4.99 & 1.15 & 9.11 \\
\hline Ho & 1.69 & 2.23 & 2.07 & 5.26 & 0.72 & 0.66 & 0.72 & 3.82 & 4.16 & 1.90 & 0.85 & 0.25 & 1.56 \\
\hline Er & 4.80 & 6.24 & 5.86 & 14.9 & 2.00 & 1.65 & 1.72 & 11.3 & 10.1 & 5.00 & 1.99 & 0.75 & 3.39 \\
\hline $\mathrm{Tm}$ & 0.77 & 0.98 & 0.94 & 2.30 & 0.29 & 0.20 & 0.22 & 1.75 & 1.24 & 0.68 & 0.24 & 0.12 & 0.34 \\
\hline $\mathrm{Yb}$ & 5.33 & 6.67 & 6.41 & 15.4 & 1.92 & 1.21 & 1.33 & 11.3 & 7.03 & 3.98 & 1.31 & 0.89 & 1.69 \\
\hline Lu & 0.80 & 0.99 & 0.94 & 2.27 & 0.29 & 0.19 & 0.21 & 1.65 & 0.85 & 0.51 & 0.20 & 0.14 & 0.25 \\
\hline $\mathrm{Hf}$ & 7.00 & 6.13 & 6.15 & 12.6 & 5.51 & 6.43 & 6.45 & 4.93 & 11.0 & 5.86 & 7.33 & 4.45 & 10.0 \\
\hline $\mathrm{Ta}$ & 0.77 & 0.75 & 0.76 & 1.38 & 0.68 & 0.28 & 0.25 & 0.49 & 0.53 & 1.22 & 0.26 & 0.46 & 0.96 \\
\hline$(\mathrm{La} / \mathrm{Yb}) \mathrm{n}$ & 3.99 & 3.34 & 3.66 & 2.85 & 24.60 & 55.33 & 35.30 & 1.44 & 8.79 & 10.90 & 36.40 & 13.97 & 44.26 \\
\hline$(E u) n / E u$ & 0.30 & 0.16 & 0.41 & 0.30 & 0.46 & 0.38 & 0.37 & 0.35 & 0.34 & 0.45 & 0.32 & 0.16 & 0.22 \\
\hline
\end{tabular}


Table 4. Sm-Nd isotopic data for rocks of the PGC. Keys: SyGr = Syenogranite; MzGr = Monzogranite; QMz = Q uart monzonite; QSy = Q uart syenite.

\begin{tabular}{|c|c|c|c|c|c|c|c|c|c|c|}
\hline Sample & Unit & Rock & Sm (ppm) & Nd (ppm) & ${ }^{147} \mathrm{Sm} / /^{144} \mathrm{Nd}$ & ${ }^{143} \mathrm{Nd} /{ }^{144} \mathrm{Nd}$ & $\varepsilon_{(0)}$ & $f_{\mathrm{Sm} / \mathrm{Nd}}$ & $\mathrm{T}_{\mathrm{DM}}(\mathrm{Ga})$ & $\varepsilon_{(11)}$ \\
\hline PF0501 & Piso Firme & QSy & 6.830 & 30.375 & 0.1360 & 0.51223 & -7.99 & -0.31 & 1.59 & 2.32 \\
\hline SC10502 & San Cristobal & $\mathrm{MzGrBi}$ & 7.826 & 32.431 & 0.1459 & 0.51234 & -5.87 & -0.26 & 1.58 & 2.75 \\
\hline SC20503 & San Cristobal & $\mathrm{MzGrBi}$ & 9.647 & 40.460 & 0.1442 & 0.51232 & -6.28 & -0.27 & 1.59 & 2.63 \\
\hline PRV0504 & Porvenir & SyGrHb & 19.278 & 79.089 & 0.1474 & 0.51229 & -6.89 & -0.25 & 1.74 & 1.48 \\
\hline CP0505 & Diamantina & SyGrBi & 10.664 & 63.260 & 0.1019 & 0.51183 & -15.7 & -0.48 & 1.65 & 0.39 \\
\hline CP20506 & Diamantina & SyGrBi & 12.872 & 78.696 & 0.0989 & 0.51179 & -16.6 & -0.50 & 1.66 & 0.03 \\
\hline CP30507 & Diamantina & SyGrBi & 13.279 & 70.132 & 0.1145 & 0.51186 & -15.2 & -0.42 & 1.82 & -1.25 \\
\hline ME0508 & Diamantina & QMzBi & 5.738 & 23.615 & 0.1469 & 0.51220 & -8.51 & -0.25 & 1.92 & -0.06 \\
\hline CA0509 & San Martín & SyGrHb & 25.353 & 107.634 & 0.1424 & 0.51226 & -7.43 & -0.28 & 1.68 & 1.78 \\
\hline FLT0510 & La Junta & SyGr & 18.727 & 99.733 & 0.1135 & 0.51173 & -17.8 & -0.42 & 2.01 & -3.66 \\
\hline LJ10511 & La Junta & QMzBi & 14.692 & 80.734 & 0.1100 & 0.51172 & -17.9 & -0.44 & 1.95 & -3.21 \\
\hline LJ20512 & La Junta & $\mathrm{MzGrBi}$ & 3.599 & 22.018 & 0.0988 & 0.51164 & -19.6 & -0.50 & 1.87 & -2.94 \\
\hline LJ30513 & La Junta & $\mathrm{MzGrHb}$ & 18.697 & 100.573 & 0.1124 & 0.51169 & -18.6 & -0.43 & 2.04 & -4.29 \\
\hline
\end{tabular}

Table 5. Sr isotopic data for rocks of the PGC. Keys: SyGr = Syenogranite; MzGr = Monzogranite; QMz = Q uart monzonite; QSy = Q uart syenite. T(Ma)=1.33 G a calculated according as a SHRIMP U/Pb age (Boger et al., 2005).

\begin{tabular}{|c|c|c|c|c|c|c|c|c|}
\hline Unit & Sample & Rock & $\begin{array}{c}\mathrm{Rb} \\
(\mathrm{ppm})\end{array}$ & $\begin{array}{c}\mathrm{Sr} \\
(\mathrm{ppm})\end{array}$ & $1 / \mathrm{Sr}$ & $\begin{array}{c}{ }^{87} \mathrm{Sr} /{ }^{86} \mathrm{Sr} \\
(\mathrm{Y})\end{array}$ & $\begin{array}{c}{ }^{87} \mathrm{Rb} /{ }^{86} \mathrm{Sr} \\
(\mathrm{X})\end{array}$ & $\begin{array}{c}\left.{ }^{87} \mathrm{Sr} /{ }^{86} \mathrm{Sr}\right) \mathrm{t} \\
\mathrm{p} / \mathrm{T}(\mathrm{Ma})\end{array}$ \\
\hline Piso Firme & PF0501 & QSy & 111.59 & 27.68 & 0.0361 & 0.72473 & 11.687 & \\
\hline San Cristobal & SC10502 & $\mathrm{MzGrBi}$ & 157.45 & 27.69 & 0.0361 & 1.03027 & 16.979 & 0.70656 \\
\hline San Cristobal & SC20503 & $\mathrm{MzGrBi}$ & 170.66 & 71.97 & 0.0139 & 0.83417 & 6.949 & 0.70169 \\
\hline Porvenir & PRV0504 & SyGrHb & 183.36 & 21.98 & 0.0455 & 1.18192 & 25.278 & \\
\hline Diamantina & CP0505 & SyGrBi & 271.15 & 224.81 & 0.0044 & 0.76889 & 3.512 & 0.70194 \\
\hline Diamantina & CP20506 & SyGrBi & 228.71 & 207.95 & 0.0048 & 0.76477 & 3.201 & 0.70370 \\
\hline Diamantina & CP30507 & SyGrBi & 301.01 & 167.87 & 0.0060 & 0.79670 & 5.235 & \\
\hline Diamantina & ME0508 & QMzBi & 232.91 & 166.14 & 0.0060 & 0.78021 & 4.086 & 0.70230 \\
\hline San Martín & CA0509 & SyGrHb & 158.81 & 72.92 & 0.0137 & 0.82563 & 6.376 & 0.70407 \\
\hline La Junta & FLT0510 & SyGr & 169.30 & 287.44 & 0.0035 & 0.73645 & 1.710 & 0.70386 \\
\hline La Junta & LJ10511 & QMzBi & 242.15 & 187.28 & 0.0053 & 0.77713 & 3.768 & 0.70530 \\
\hline La Junta & LJ20512 & $\mathrm{MzGrBi}$ & 140.09 & 323.02 & 0.0031 & 0.73007 & 1.258 & 0.70609 \\
\hline La Junta & LJ30513 & $\mathrm{MzGrHb}$ & 245.65 & 119.90 & 0.0083 & 0.81792 & 5.994 & \\
\hline
\end{tabular}

reas the late- to post-kinematic ones plot mainly in the syenogranite, monzogranite, quartz monzonite and quartz syenite fields in the Streckeisen QAP diagram (see Figure 3).

Syn- to late- kinematic granitoid rocks

\section{La Junta granite}

This moderately to weakly foliated body occurs in the southern part of PGC. The colour composite satellite im- agery and the surface cover of the La Junta granite do not allow defining its size because the field relations with the other rock units are not exposed. In some places the granite becomes distinctly gneissic with a well developed planar fabric. The observed anatexis is syn- to late- Do3, but an early prograde metamorphism (pre- Do3) reached highgrade metamorphism in the country rocks located close to the pluton, as evidenced by prismatic sillimanite.

According to Hawkins (1982) the La Junta granite includes numerous xenoliths of hornblende-biotite gneiss 
Table 6. Modal analysis for rocks of the PGC. All samples have Nd and Sr analyses (this work). See text for details. Keys: SyGr = Syenogranite; MzGr = Monzogranite; Q Mz = Q uart monzonite; QSy = Q uart syenite; Qz = Q uart; K-feld = K-feldspar; Plag = Plagioclase; Biot = Biotite; Horn = Hornblende; Zr = Zircon; Sph = Sphene; Magn = Magnetite; Apat = Apatite; Allan = Allanite; Epid = Epidote; Chlor = Chlorite; PF = Piso Firme; SC = San Cristobal; P = Porvenir; D = Diamantina; $\mathrm{LJ}=$ La Junta; SM = San Mart́n. * Magnetite was determined using a pocket magnet.

\begin{tabular}{|c|c|c|c|c|c|c|c|c|c|c|c|c|c|c|c|c|}
\hline Sample & Unit & Lithology & $\begin{array}{c}X \\
\text { (utm) }\end{array}$ & $\begin{array}{c}Y \\
\text { (utm) }\end{array}$ & Qz. & $\begin{array}{l}\text { Primary } \\
\text { K-feld. }\end{array}$ & $\begin{array}{l}\text { miner } \\
\text { Plag. }\end{array}$ & Biot. & Horn. & $\mathrm{Zr}$. & $\begin{array}{l}\text { Acces } \\
\text { Sph. }\end{array}$ & $\begin{array}{l}\text { sory mir } \\
\text { Magn.* }\end{array}$ & $\begin{array}{l}\text { nerals } \\
\text { Apat. }\end{array}$ & Allan. & $\begin{array}{l}\text { Seco } \\
\text { Epid. }\end{array}$ & $\begin{array}{l}\text { ndary } \\
\text { Chlor. }\end{array}$ \\
\hline PF0501 & PF & QSy & 635376 & 8493848 & 15 & 65 & 20 & & & $x$ & & $x$ & & & $x$ & \\
\hline SC10502 & SC & MzGrBi & 623763 & 8479614 & 34 & 41 & 23 & 2 & & $x$ & & $x$ & $x$ & & $x$ & \\
\hline SC20503 & SC & MzGrBi & 625302 & 8474694 & 29 & 42 & 25 & 4 & & $x$ & $x$ & & & & & \\
\hline PRV0504 & $P$ & SyGrHbBi & 653060 & 8445505 & 32 & 50 & 15 & $x$ & 3 & $x$ & & $x$ & & & $x$ & \\
\hline СР0505 & $\mathrm{D}$ & SyGrBi & 661618 & 8392877 & 27 & 54 & 14 & 5 & & $x$ & & $x$ & $x$ & & & $x$ \\
\hline CP20506 & $\mathrm{D}$ & SyGrBi & 662459 & 8385600 & 35 & 42 & 21 & 2 & & $x$ & & $x$ & $x$ & & $x$ & $x$ \\
\hline CP30507 & $\mathrm{D}$ & SyGrBi & 660835 & 8376150 & 23 & 49 & 26 & 2 & & $x$ & & $x$ & $x$ & & & \\
\hline ME0508 & $\mathrm{D}$ & QMzBi & 659335 & 8367510 & 19 & 41 & 38 & 2 & & & & $x$ & $x$ & & $x$ & \\
\hline CA0509 & SM & SyGrHb & 642653 & 8367578 & 28 & 60 & 10 & & 2 & $x$ & $x$ & $x$ & $x$ & $x$ & $x$ & $x$ \\
\hline FLT0510 & LJ & SyGrBi & 662154 & 8342436 & 25 & 46 & 21 & & & & $x$ & $x$ & $x$ & & $x$ & 8 \\
\hline LJ10511 & LJ & QMzBi & 662601 & 8324646 & 8 & 49 & 37 & 6 & & $x$ & & $x$ & $x$ & & & $x$ \\
\hline LJ20512 & LJ & MzGrBi & 681788 & 8313212 & 19 & 42 & 36 & 3 & & $x$ & $x$ & $x$ & $x$ & & $x$ & $x$ \\
\hline LJ30513 & LJ & $\mathrm{MzGrHbBi}$ & 662293 & 8309407 & 30 & 30 & 35 & 1 & 4 & & & $x$ & $x$ & & $x$ & \\
\hline
\end{tabular}

partly migmatitic, calc-silicate gneiss, quartzite and amphibolite. This author classified the La Junta granite as a porphyritic rock, medium-to coarse-grained with biotite and hornblende. In addition to our analyses (FLT0510, LJ10511, LJ20512, LJ30513), the QAP diagram includes data from Hawkins (1982) (dark gray field in Figure 3). The resulting feature indicates that the La Junta pluton is constituted by gneisses of monzogranitic to syenogranitic composition. Sample FLT0510 is a pinkish, coarse-grained syenogranite gneiss, and consists of K-feldspar and plagioclase surrounded by a irregularly streaky chlorite accompanied by epidote, also strongly replaced by sericite shreds that are pale gray in color and cloudy. Sample LJ10511, one biotite, quartz monzonitic gneiss, has apatite, whereas sample LJ20512, one medium leucocratic biotitic monzogranitic gneiss, has sphene as the principal accessory mineral. Sample LJ30513 is a hornblende monzogranite, white pinkish in color, medium to coarse grained, isotropic to moderately foliated and porphyritic.

\section{San Martín granite}

This pluton crops out extensively in the western side of PGC (Figure 2). It is a heterogeneous batholith, partly migmatitic, granitic gneiss of autochtonous character (Klinck and O'Connor, 1983). The investigated sample (CA0509) has a syenogranite composition in the QAP diagram (Figure 3). In the central part of the batholith banded

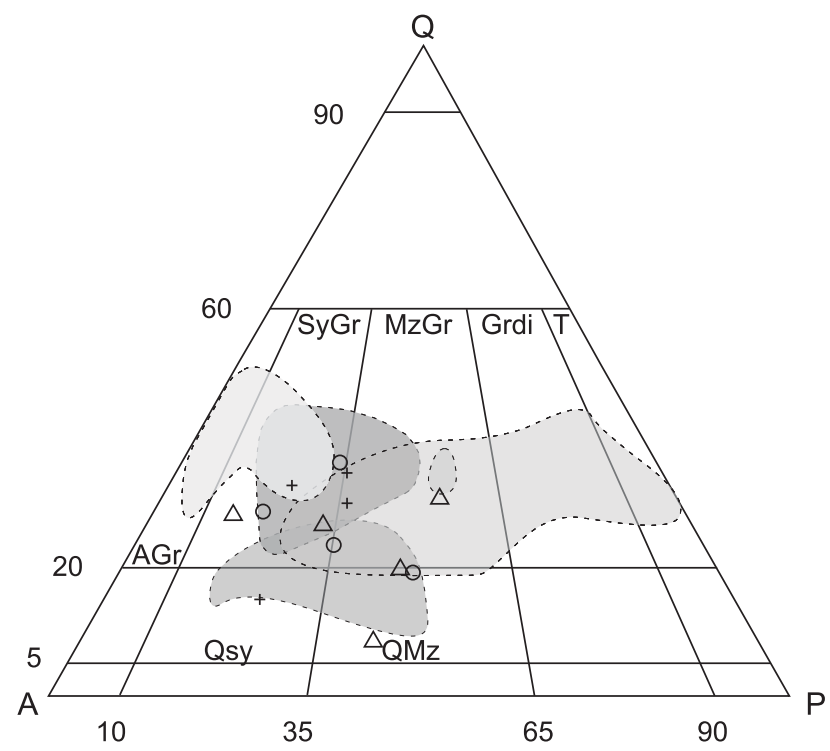

Figure 3. Streckeisen Q AP diagram for selected samples of the PG C. $\mathrm{T}=$ Tonalite; Grdi = Granodiorite; $\mathrm{MzGr}=$ Monzogranite; SyGr = Syenogranite; $A G r=$ Alkali-feldspar granite; $\mathrm{QMz}=\mathrm{Q}$ uart monzonite; QSy = Q uart syenite. + = Lateto post-kinematic granites; $O=$ Diamantina granite; $\triangle=$ Synto late kinematic granites. All samples have $\mathrm{Nd}$ and $\mathrm{Sr}$ isotopic data (this work); see text for details. Keys: $\bigcirc$ - La Junta granite (modified from Hawkings, 1982); $\bigcirc$ - Diamantina Granite (modified from Litherland, 1982); - Diamantina Granite (modified from Klink and O 'Connor, 1982); $\bigcirc$ - Piso Firme Granophyre (modified from Piffield, 1983); $\bigcirc$ - San Cristobal Metagranite (modified from Pitfield, 1983). 
enclaves of migmatitic biotite gneiss show both concordant and discordant contacts with the granite injections. The biotite defines a weak foliation, but lens- or augentexture are observed in places. Along the western side of the batholith the distribution of the isogrades indicates medium grade metamorphic conditions. The most representative rock exhibits a granular texture and biotite flakes and prismatic hornblende. The K-feldspar form scattered phenocrysts from 1.5 to $3 \mathrm{~cm}$ long. In the southern part the San Martín pluton becomes melanocratic.

\section{Late- to post -kinematic granitoid rocks}

\section{Piso Firme granophyres}

This rock crops out nearby Piso Firme village in Beni department, in the vicinity of Paraguá river (PF samples; Figure 2) The colour composite satellite imagery shows this pluton as wooded hills with the principal fractures following E-W direction and subordinately NNW trend. The east-west long axis of the intrusion is $6 \mathrm{~km} v s .3 \mathrm{~km}$ wide along the NS direction.

The Piso Firme granophyre (Pitfield, 1983) comprises three distinctive lithologic facies from north to south: a) coarse to medium-grained potassic granophyre (sample PF0501 in the present work); b) medium to coarse-grained microespherulitic granophyre; c) spherulitic plagiophyric microgranophyre. One aegirine-riebeckite-bearing sodicpotassic granophyre crops out as a small hillrock that was previously described in the eastern side of Cerro Piso Firme (Pitfield, 1983). The QAP diagram includes the new data and those from Pitfield (1983) (light gray field; Figure 3). The investigated samples fall between the syenogranite and the alkali-feldspar granite fields.

\section{Porvenir granite}

This body, first characterized near the homonymous village, crops out as positive topographic feature, such as the Pica Pica hill (sample PRV0504; Table 6) located to the eastern side from the road to Piso Firme and Cerro Porvenir (Figure 2). On the color composite satellite imagery this intrusion forms a forested hill raising no more than 60 $100 \mathrm{~m}$ above the plain. It shows a roughly shape with fractures of joints following NW direction, sometimes gently curved (Klinck and O'Connor, 1983). Following its long NW oriented axis the outcrop is $10-12 \mathrm{~km}$ long, and the width of the intrusion in the NW direction is 2 to $5 \mathrm{~km}$. The investigated outcrop is an isotropic, medium-fine grained, massive hornblende syenogranite to weakly foliated monzogranite. These compositions are displayed by the samples plotted in the QAP diagram (Figure 3). The quartz appears as polygonal grained aggregates, and K-feldspar is partly replaced by sericite. Plagioclase is very subordinate. Hornblende forms irregular shaped grains commonly in aggregates. The observed granoblastic textures suggest a post-tectonic metamorphism, in agreement with the low grade metamorphism (actinolite+epidote+chlorite) reported by Klinck and O'Connor (1983) in rocks located $7.5 \mathrm{~km}$ to the SW of the Porvenir granite.

\section{San Cristobal granite}

This granite makes up the Leyton hill (samples SC10502 and SC20503; Figures 2, 3 and Table 6), among many other hills named Serranía San Cristobal - a NW oriented ridge which is clearly seen in the colour composite satellite imagery. In general, the rock in Leyton hill is a homogeneous, biotitic monzogranite that locally grades or is emplaced into concordant zones of the gneisses of the crystalline basement. Banded porphyroblastic gneiss and pegmatite are also present. From the above the San Cristobal granite can be classified as a moderately to smooth streaky granitic gneiss. Its N-NW foliation (Do3) is assigned to be tectonically related with the San Ignacio orogeny (e.g., Litherland et al., 1986). The rock is pinkish in hand sample, and in the thin section quartz is anhedral with undulose extinction, K-feldspar consists of irregular microcline twinning and plagioclase occurs as tabular crystals with fine and coarse twinning. In the QAP diagram (Figure 3 ) our data in conjunction with those from Pitfield (1983) plot in the monzogranite field.

\section{Diamantina granite}

This intrusion makes up a north trending hill, forming a large elliptical body about $53 \mathrm{~km}$ long (Klinck and O'Connor, 1983), that crops out as an "island" in the forest, close to the road to Piso Firme village (Figure 2). The northern and central parts of the Diamantina granite are made up by several outcrops that exhibit two clear systems of joints $\left(80^{\circ}\right.$ and $\left.170^{\circ}\right)$. In the southern part the outcrops appear as small sprinkled mottled aspect.

According to Klinck and O'Connor (1983) the Diamantina pluton was formed by distinct intrusive phases: first magmatic phase produced granodiorite and/or tonalite. After cooling of these rocks, a second phase (monzogranite) intruded the earlier granodiorite-tonalite, as shown by the typical xenoliths with spherical to tabular forms (50 cm to $43 \mathrm{~m}$ long). They are also fine-grained and sometimes medium and coarse grained and may contain biotite as the principal mafic mineral. Other xenoliths comprise exotic lithologies (biotite gneisses, garnet-biotite gneiss and hornblende gneisses) with irregular distri- 
bution. The northern side of the Diamantina granite is xenoliths free compared to the southern side. Some lenses and veins of pegmatites are present. The Diamantina granite represents either the last magmatic post-tectonic phase of the PGC (Klinck and O'Connor, 1983) or shortly succeeded Do3 episode (Litherland, 1982).

The Diamantina granite was sampled in four places (Figure 2). The dominant rock type is a pale pink and non foliated biotitic syenogranite. One sample (ME0508; moderately foliated biotitic quartz monzonite), collected at La Mechita farm was previously considered as belong to the Chiquitania Complex by Litherland 1:1.000.000 map. However, it was herein considered as representative of the Diamantina intrusion based in the field relationships of our work.

The QAP diagram (Figure 3; Table 6) shows our analyses and the published ones (Klinck and O'Connor, 1983) that were sampled in the western side of the Diamantine granite (medium gray field). The previous data indicate a transition from tonalite to syenogranite in composition, but the new analyses fall mainly within the monzogranite field. In addition, Figure 3 shows the data from Litherland (1982) (dark- medium gray field) referring to the samples from the eastern side of the body. This distinct samples show a transition from intermediate rocks of quartz monzonite to syeno-granite.

\section{Major and trace elements}

Table 3 presents the major and trace elements data of thirteen samples of PGC.

\section{Syn- to late-kinematic granitoid rocks}

Four samples of the La Junta granite (FLT0510, LJ10511, LJ20512, LJ30513) and one of the San Martín granite (CA0509) show $\mathrm{SiO}_{2}$ contents from 69 to 77 $\mathrm{wt} \%$. Major oxides display regular trends of decreasing $\mathrm{Al}_{2} \mathrm{O}_{3}, \mathrm{MgO}, \mathrm{CaO}$ and $\mathrm{Fe}_{2} \mathrm{O}_{3 \text { Tot }}$ with increasing $\mathrm{SiO}_{2}$ contents suggesting that fractional crystallization played an important role in the petrogenetic process (Figure 4). Figures $5 \mathrm{~A}$ to $5 \mathrm{C}$ present variation diagrams of $\mathrm{Zr}$, Ba and Sr against $\mathrm{SiO}_{2}$ showing roughly decreasing of the trace elements with increasing $\mathrm{SiO}_{2}$. This behavior is probably due to zircon, feldspar and plagioclase separation from the evolving melts. Figure 5D ( $\mathrm{Rb} / \mathrm{Sr}$ vs. $\mathrm{Sr} / \mathrm{Ba}$ ) shows linear trends for the samples, which suggests again the hypothesis of fractional crystallization. All the investigated samples, including those from syn- to late-kinematic plutons reported in the literature (Litherland et al., 1986), are subalkaline (Figures 6A and 6B), as indicated by the characteristic $\mathrm{Na}_{2} \mathrm{O}+\mathrm{K}_{2} \mathrm{O}$ values $<$ to $8.5 \mathrm{wt} \%$ (Table 3) (see, e.g., Nardi and Bonin, 1991). In addition the La Junta and San
Martín samples show mainly a high-K and calc-alkaline affinity with $\mathrm{SiO}_{2}$ content higher than 69 wt\% (see Figures 7 and 8) suggesting they have an arc-related geochemical signature. The highest-K tendency of FLT0510 and LJ10511 samples is probably due to the feldspar and plagioclase alterations $\left(\mathrm{K}_{2} \mathrm{O} / \mathrm{Na}_{2} \mathrm{O}\right.$ ratio of 2.56 and 2.25 respectively; see Table 3 ), that originate sericite as cloudy masses and minute shreds. Therefore the whole rock compositions of these particular samples were modified toward apparent peraluminosity (Figure 8).

The REE patterns of the La Junta and San Martín granite samples (Figure 9) are moderately fractioned in terms of LREE/HREE with a slightly negative Eu anomaly. In the spider diagram the samples present steep patterns due to their high LILE contents which compare well with the typical pattern of Andean-type igneous rocks (segmented line in Figure 10). The observed negative peaks of Sr, P, and Ti suggest fractionation of feldspars, apatite, and titano-magnetite and sphene, respectively. Sample LJ20512 presents a contrasting signature with no negative Eu anomaly (Figure 9), suggesting either one depleted REE source, or fractionation with amphibole and/or allanite in the residue. The lower values of $\mathrm{Ta}$ and $\mathrm{Nb}$ in the sample LJ20512 may be ascribed to crustal contamination.

\section{Late- to post -kinematic granitoid rocks}

Major and trace elements data of four samples from Porvenir and San Cristobal granites and Piso Firme granophyre are given in Table 3. In the Harker's diagram (Figure 4), the samples display negative correlations for $\mathrm{Al}_{2} \mathrm{O}_{3}$, $\mathrm{MgO}, \mathrm{CaO}$ and $\mathrm{Fe}_{2} \mathrm{O}_{3 \text { Tot }}$ with increasing $\mathrm{SiO}_{2}$ contents and a positive correlation to the $\mathrm{Na}_{2} \mathrm{O}$, suggesting the role of fractional crystallization process. The plots of $\mathrm{Zr}, \mathrm{Ba}$ and $\mathrm{Sr}$ against $\mathrm{SiO}_{2}$, show decreasing of the trace elements with the increasing contents of $\mathrm{SiO}_{2}$ (Figure 5) which is probably due to zircon, feldspar and plagioclase separation from the evolving melts. On the $\mathrm{Rb} / \mathrm{Sr} v s$. $\mathrm{Sr} / \mathrm{Ba}$ diagram (Figure 5D), the studied samples show a linear trend, which is consistent again with fractional crystallization. All the samples are sub-alkaline (Figure 6), in agreement with their characteristic $\mathrm{Na}_{2} \mathrm{O}+\mathrm{K}_{2} \mathrm{O}$ values (Table 3 ).

The investigated late- to post -kinematic rocks have narrow range in the $\mathrm{SiO}_{2}$ contents (from 74 to $76 \mathrm{wt} \%$ ) and plot in the high-K field likewise most of the syn- to late-kinematic rocks (Figures $8 \mathrm{~A}$ and $8 \mathrm{~B}$ ). The Piso Firme granophyre and San Cristobal granite have metaluminous composition and the Porvenir granite (Figure 9), show a tendency to peraluminous character $(\mathrm{ACNK}=1.03)$. These three plutons have $\mathrm{K}_{2} \mathrm{O} / \mathrm{Na}_{2} \mathrm{O}$ ratios that range from 0.9 to 1.4 (see Table 2). Regarding the REE patterns, all the samples show low LREE fractionation, and subhorizontal tendency of HREE 


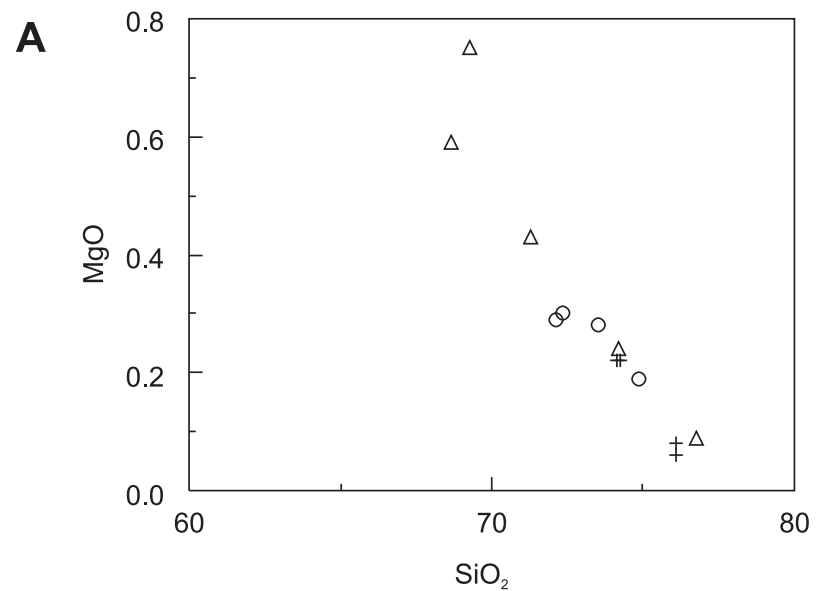

B
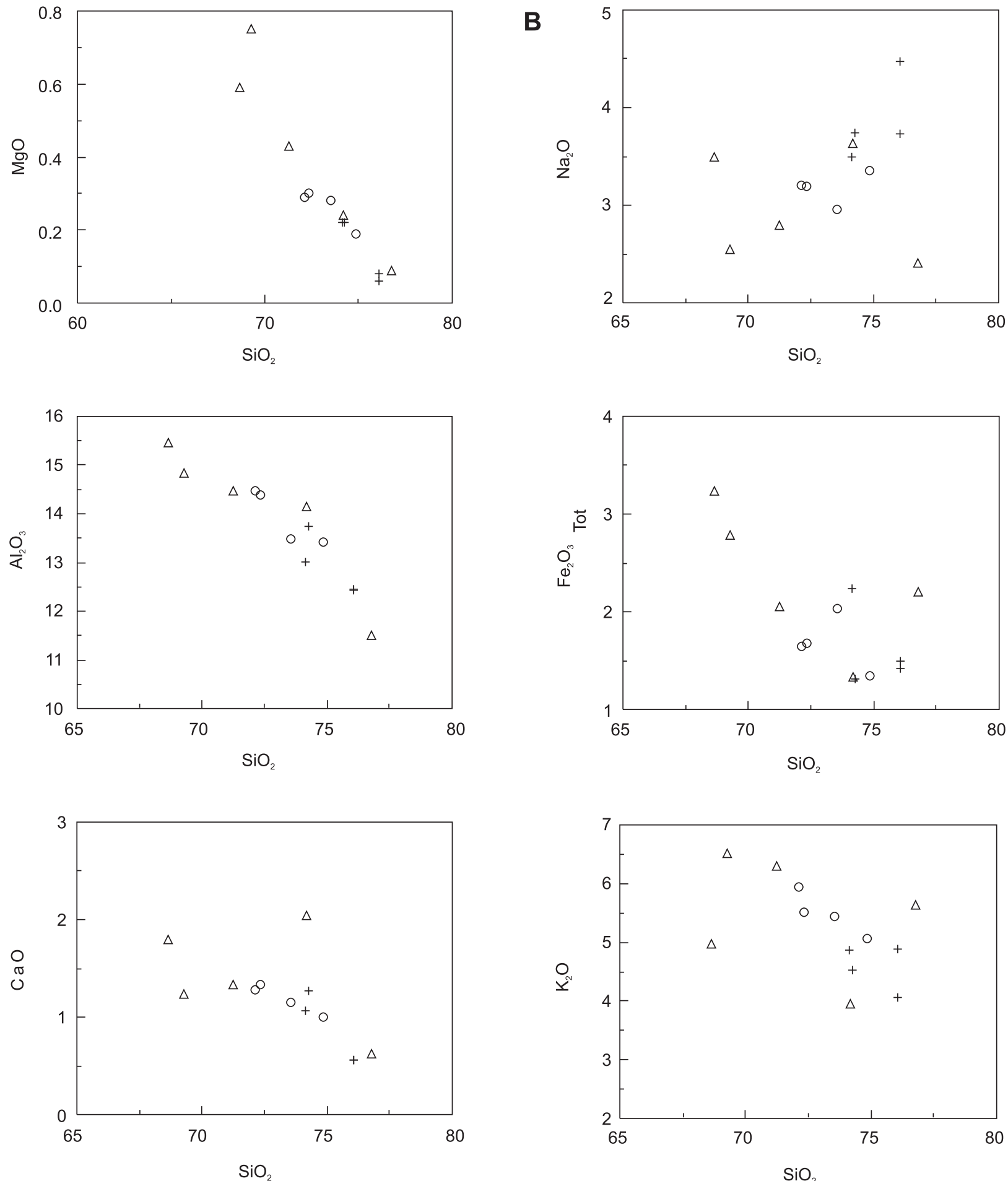
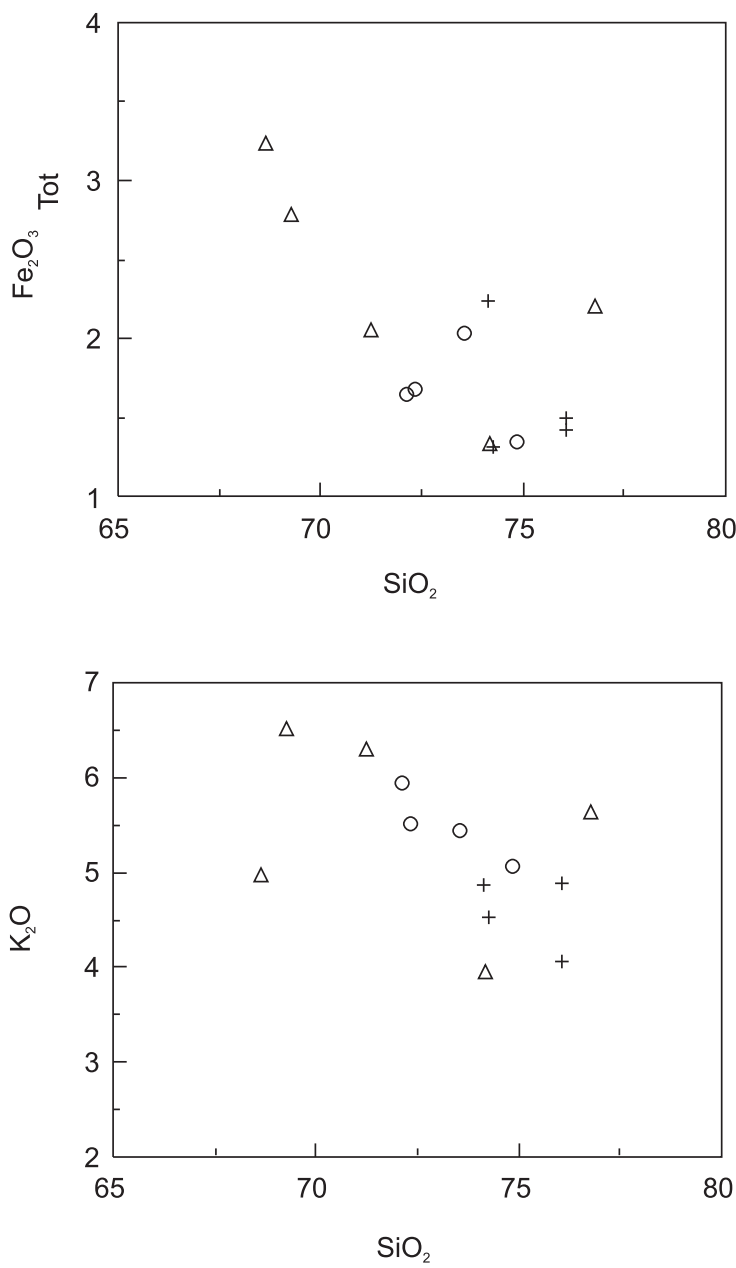

Figure 4. Variation diagrams of major elements for the PGC. Symbols as shown in Figure 3. 
A

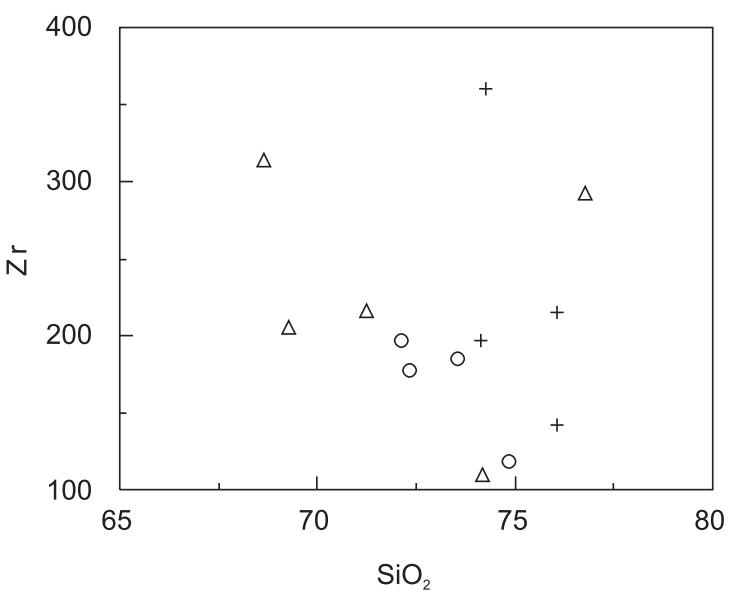

C

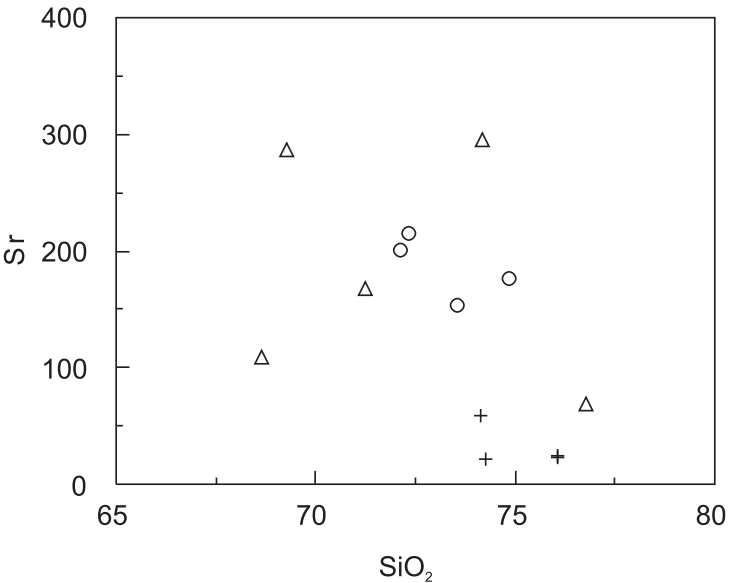

B

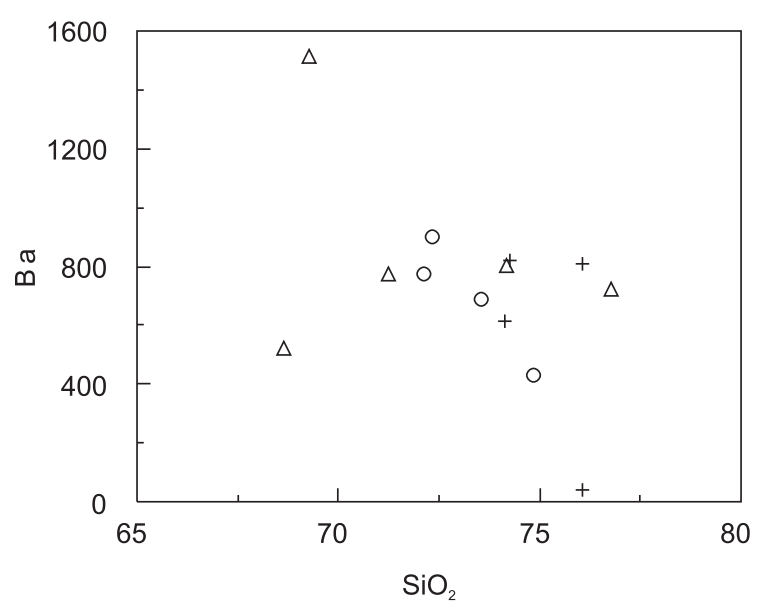

D

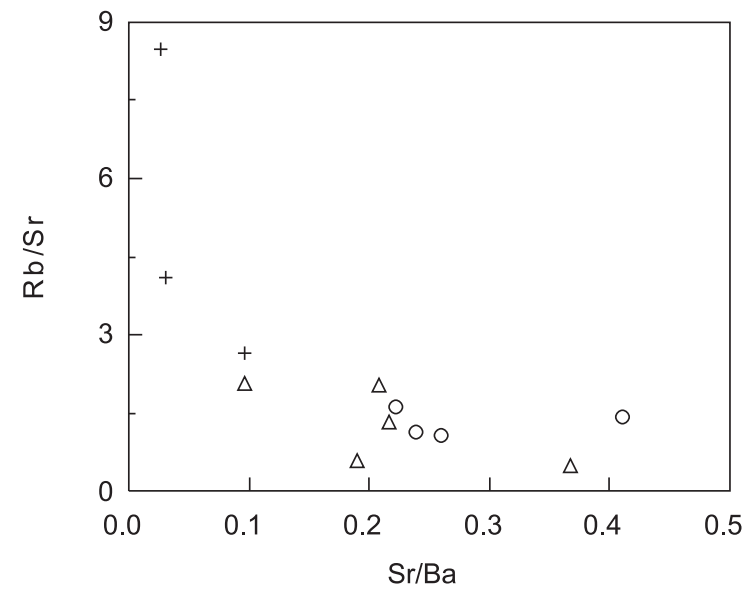

Figure 5. Variation diagrams of trace elements vs. $\mathrm{SiO}_{2}$ for $\mathrm{PGC}$ rocks. $5 \mathrm{~A}$. $\mathrm{Zr}$ vs. $\mathrm{SiO}_{2} .5 \mathrm{~b}$. Ba vs. 2. 5C. Sr vs. $\mathrm{SiO}_{2}$. $5 \mathrm{D} . \mathrm{Rb} / \mathrm{Sr}$ vs. Sr/Ba. Symbols as shown in Figure 3. 
A

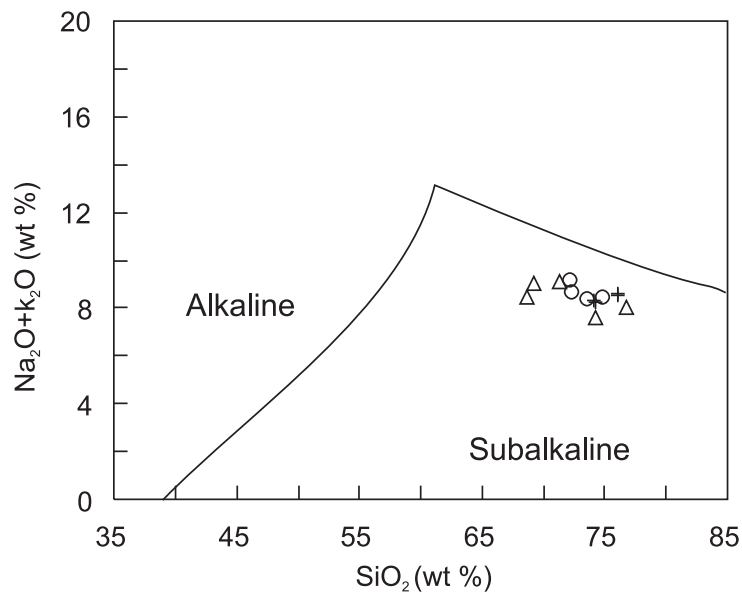

B

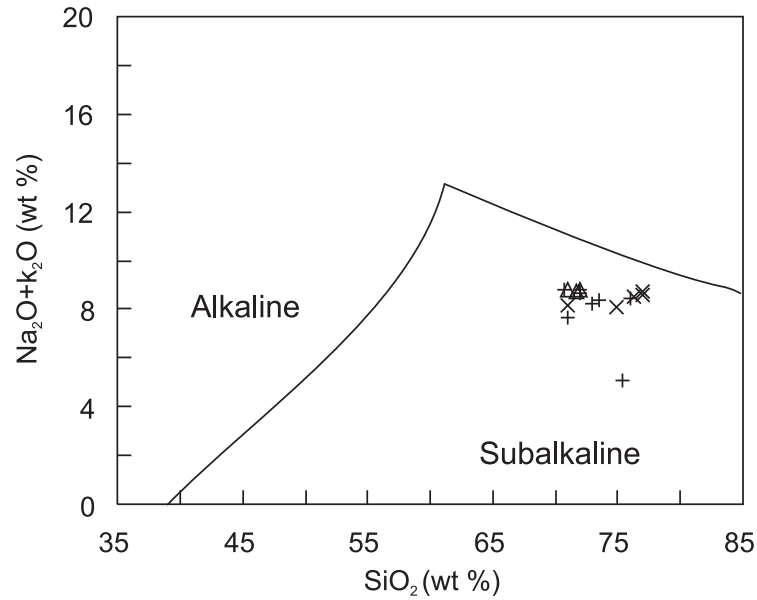

Figure 6. A. Plot of the PGC rocks (this work) in the total alkalis vs. silica diagram; modified from Middlemost (1985). Symbols as shown in Figure 3. B. Plot of PG C rocks from Litherland et al. (1986) in the total alkalis vs. silica diagram; modified from Middlemost (1985). with negative Eu anomaly. This probably reflects plagioclase and/or feldspar fractionation process (Figure 9B). They are slightly less enriched in LILE compared to the syn-to late-kinematic granitoid rocks, and also have deeper negative peaks of Sr, P and Ti reflecting once more the role of fractional crystallization (see Figure 11).

Four samples of the Diamantina granite show $\mathrm{SiO}_{2}$ content from 72 to $75 \mathrm{wt} \%$, and plot within the high-K field (Figure 7), with a peraluminous composition (Figure 8). The $\mathrm{K}_{2} \mathrm{O} / \mathrm{Na}_{2} \mathrm{O}$ ratio of the Diamantina samples varies from 1.5 to 1.8 , suggesting their pristine character. They show two different REE signatures (Figure 9): 1. samples CP0505, CP20506 and CP30507 exhibit steep patterns compared with the Piso Firme, San Cristobal and Porvenir granitoid rocks. This is related with the LREE high contents and depletion in HREE, probably reflecting amphibole fractionation and/or allanite; 2. sample ME0508 shows "gull wingshaped" REE pattern with moderate negative Eu anomaly, typical of differentiated granites (Figure 9C). In the multi-element diagrams, the samples show a pattern similar to the syn- to late-kinematic plutons (see Figure 10) with the negative peaks of $\mathrm{Sr}, \mathrm{P}$, and $\mathrm{Ti}$ which are interpreted as due to fractionation of mica, feldspar, apatite, and Ti phases (Figure 11C).

\section{$\mathrm{Nd}-\mathrm{Sr}$ isotopes}

The $\mathrm{Nd}$ and $\mathrm{Sr}$ isotopic parameters of the investigated PGC rocks were recalculated according as reference SHRIMP U/Pb age of $1.33 \mathrm{Ga}$ (zircon rims) reported for the San Rafael granite, and interpreted as the emplacement age (Boger et al., 2005).

The Sm-Nd whole rock analyses for the syn- to latekinematic granitoid rocks yielded "normal" crustal (plutonic rocks) $f_{\mathrm{Sm} / \mathrm{Nd}}$ ratios of -0.28 (San Martín) and -0.42 to -0.50 (La Junta). Their $\mathrm{T}_{\mathrm{DM}}$ model ages are $1.67 \mathrm{Ga}$ and in the range 1.87 to $2.04 \mathrm{Ga}$, respectively (Table 4$)$. The $\varepsilon_{\mathrm{Nd}(1.33 \mathrm{Ga})}$ value for the San Martín granite is +1.8 whereas the La Junta samples show contrasting negative values between -2.9 to -4.3 (Table 4 ). The late- to post kinematic San Cristobal, Porvenir and Piso Firme plutons show roughly comparable $f_{\mathrm{Sm} / \mathrm{Nd}}$ ratios (-0.31 and -0.25), similar $\mathrm{T}_{\mathrm{DM}}$ model ages $(1.6$ to $1.7 \mathrm{Ga})$ and positive $\varepsilon_{\mathrm{Nd}(1.33 \mathrm{Ga})}$ values of +2.7 to +1.5 (Table 4 ). In contrast, the Diamantina granite displays variable $\mathrm{T}_{\mathrm{DM}}$ model ages between 1.6 and $1.9 \mathrm{Ga}\left(f_{\mathrm{Sm} / \mathrm{Nd}}\right.$ ratios between -0.50 and -0.25$)$, and $\varepsilon_{\mathrm{Nd}(1.33 \mathrm{Ga})}$ values from +0.4 to -1.2 . As such, the $\varepsilon_{\mathrm{Nd}(1.33 \mathrm{Ga})}$ signatures are consistent with mixing of mantle derived and short crustal residence components (e.g., Paleoproterozoic) in the petrogenetic process. This idea agrees well with the variable $\mathrm{Nd}$ contents (22 to $100 \mathrm{ppm}$ ) of the studied samples (see Table 4). 
A

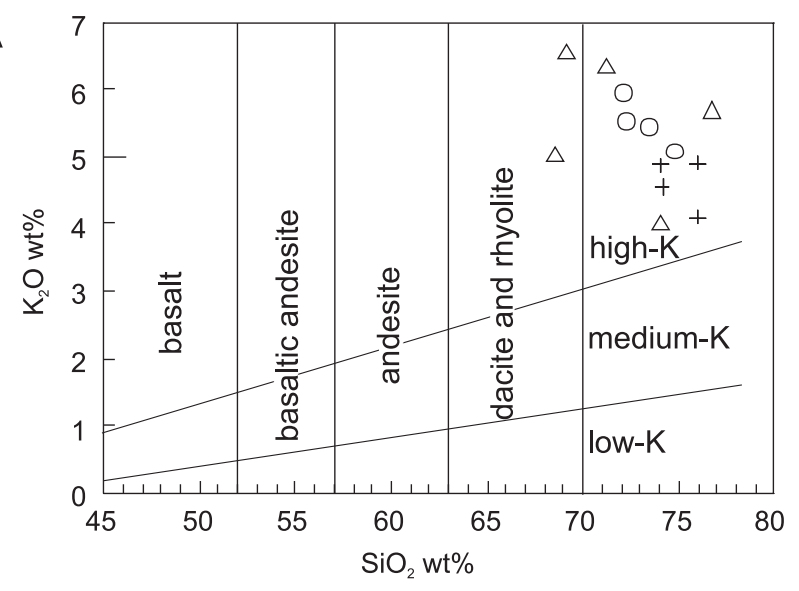

B

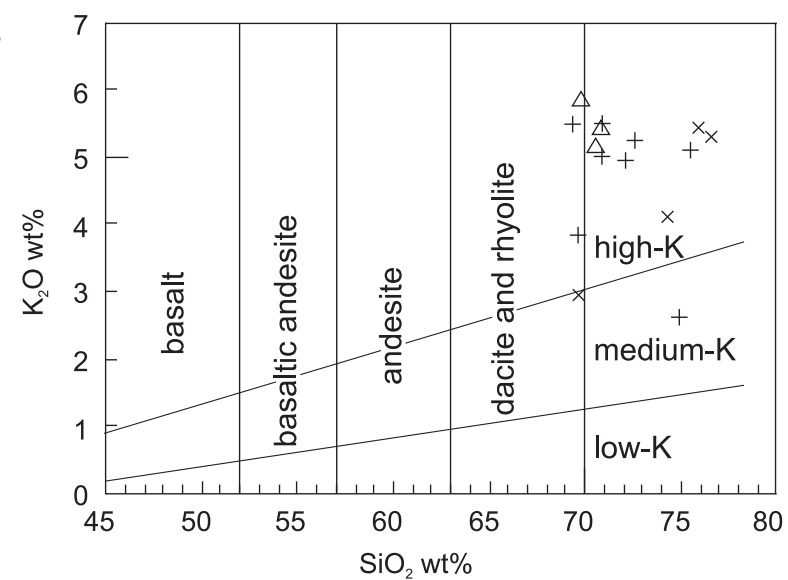

Figure 7. A. Plot of $\mathrm{PGC}$ rocks in the $\mathrm{K}_{2} \mathrm{O}$ wt $\%$ vs. $\mathrm{SiO}_{2}$ wt $\%$ diagram of Le Maitre (2002). Symbols as shown in Figure 3. B. Plot of PG C rocks reported by Litherland et al. (1986) in the $\mathrm{K}_{2} \mathrm{O}$ wt $\%$ vs. $\mathrm{SiO}_{2}$ wt\% diagram of Le Maitre (2002).
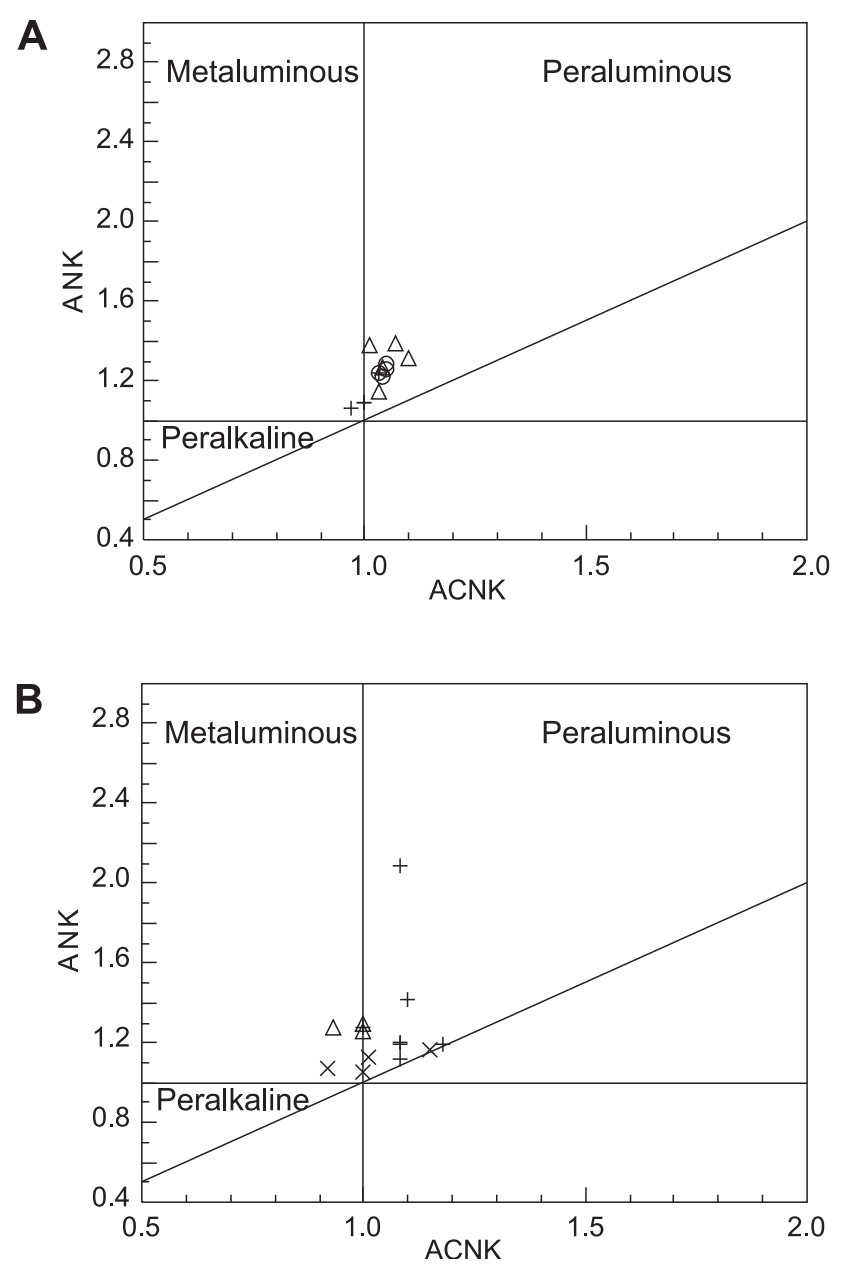

Figure 8. A. Alumina saturation diagram of Maniar and Piccoli (1989) for rocks of PG C. Symbols as shown in Figure 3. B. Alumina saturation diagram, after Maniar and Piccoli (1989) for PG C rocks (gray field), as reported by Litherland et al. (1986). 
A

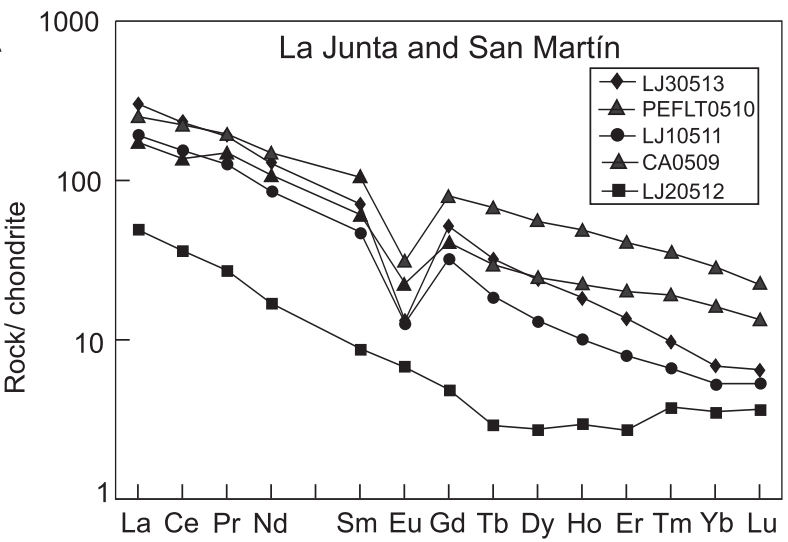

B

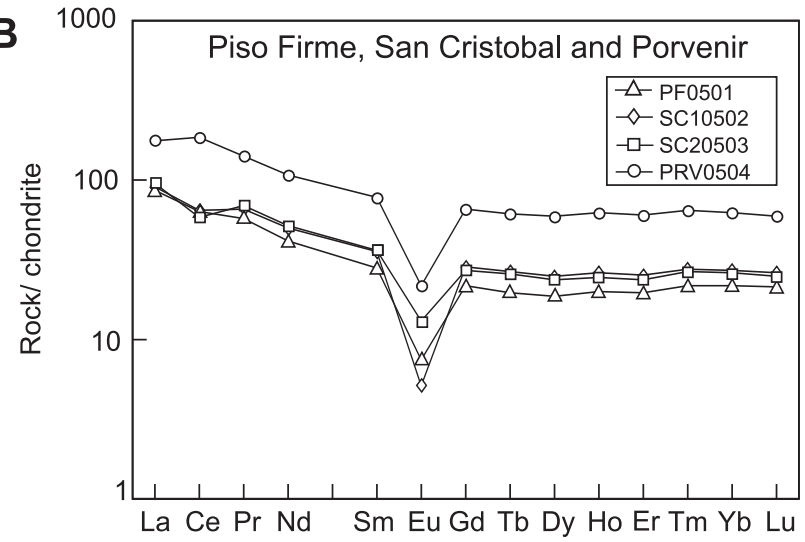

C

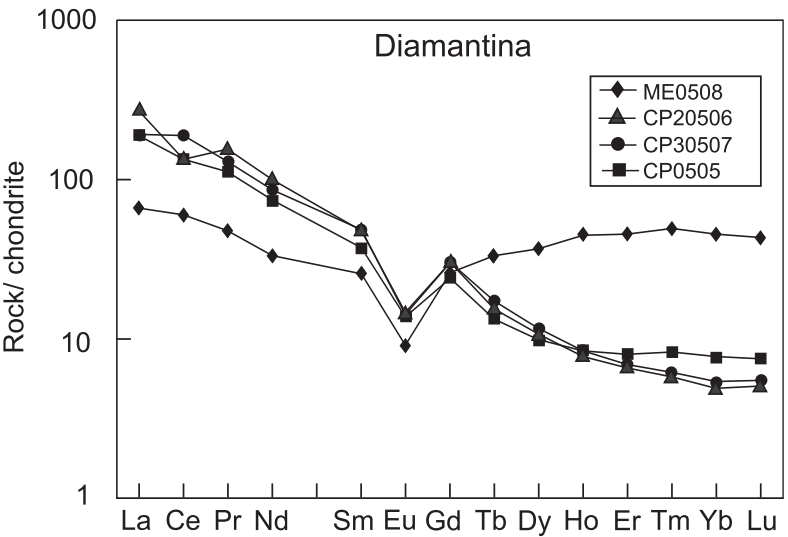

Figure 9. Chondrite-normalized REE paterns of the PGC. A. Syn- to late-kinematic granitoids (La J unta and San Martín). B. Late- to post-kinematic granitoids (San Cristobal and Porvenir and Diamantina granites and Piso Firme Granophyre). C. Diamantina G ranite $10 \mathrm{c}$. N ormalized values are from Taylor and McLennan (1985).
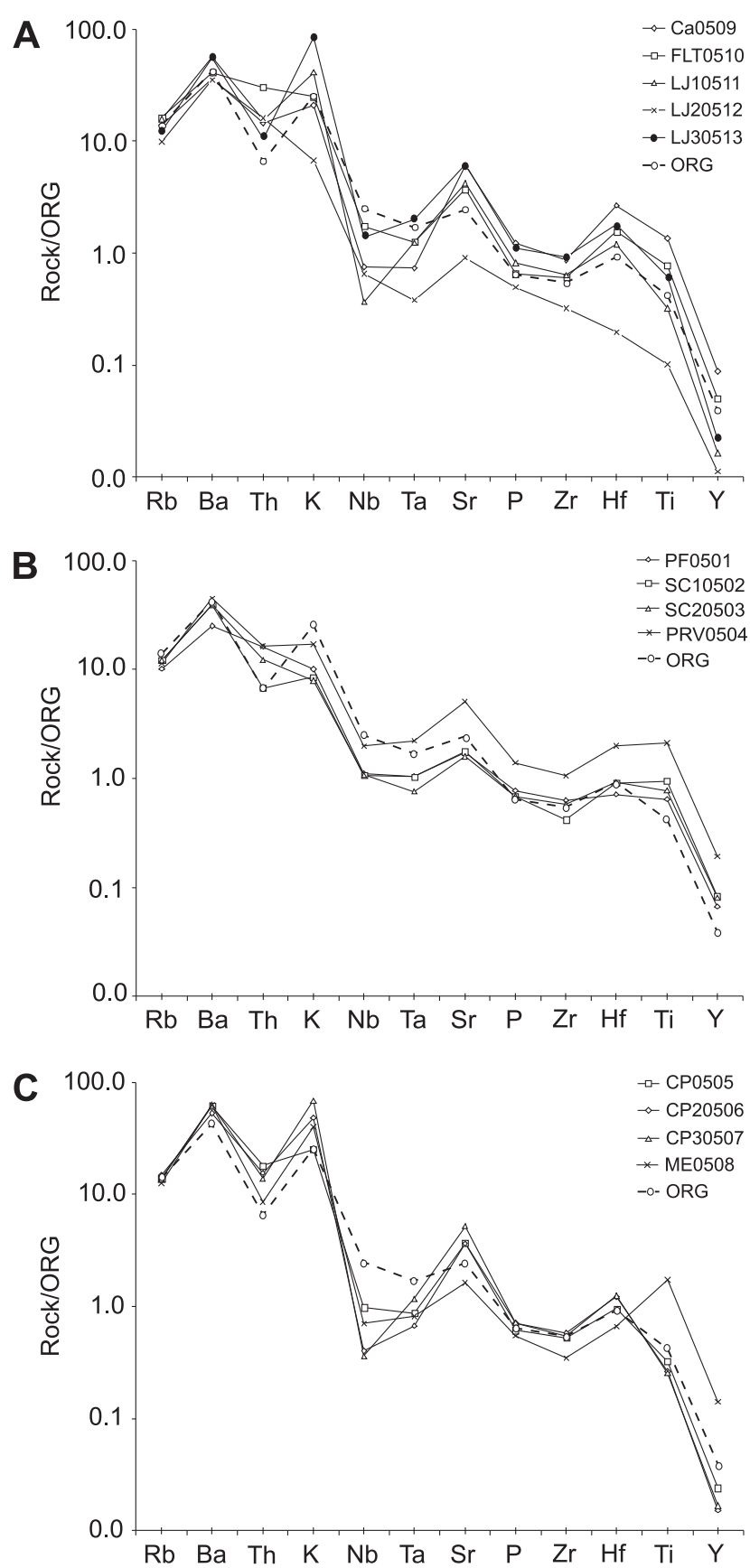

Figure 10. Trace element concentrations normalized to the O RG composition. A. Syn- to late-kinematic granitoids (La Junta and San Martín). B. Late- to post-kinematic granitoids (San Cristobal and Porvenir granites and Piso Firme granophyre). C. Late- to post-kinematic Diamantina granite. Normalizing values are from Pearce et al. (1984). 
A

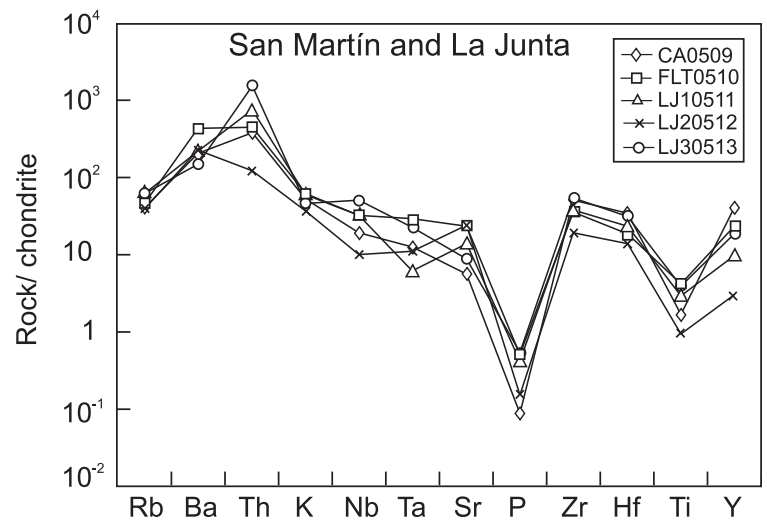

B

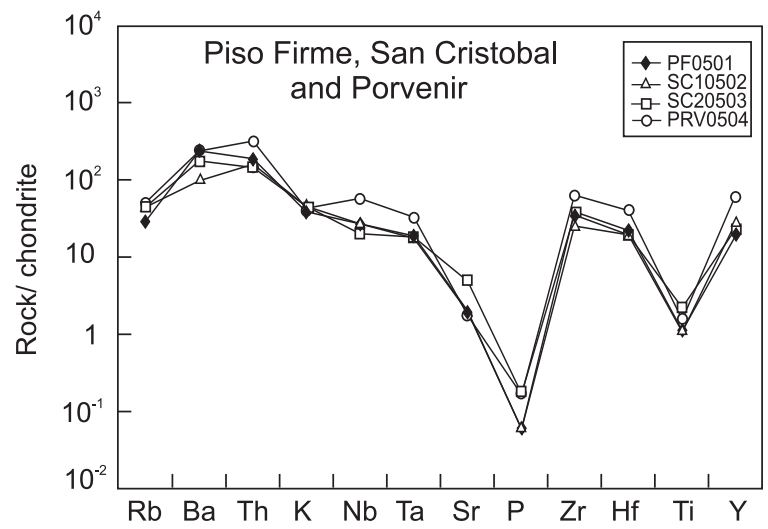

C

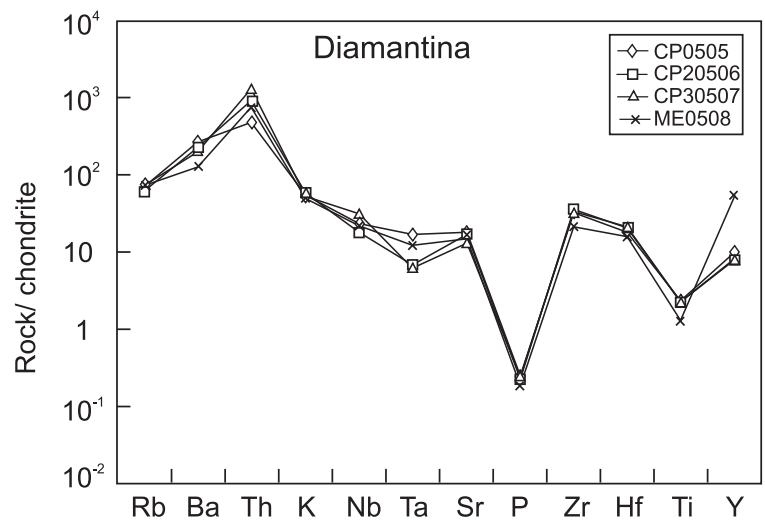

Figure 11. Trace element concentrations normalized to the composition of chondritic meteorites. The data are plotted from left to right according with the increasing compatibility to PGC samples. A. Syn- to late-kinematic granitoids (La Junta and San Martín). B. Late- to post-kinematic granitoids (San Cristobal and Porvenir granites and Piso Firme Granophyre). C. Diamantina Granite. Normalized values are from Taylor and McLennan (1985).
Figure 12 provides additional clues for the petrogenetic inferences of the PGC samples by recalculating the $\varepsilon_{\mathrm{Nd}(t)}$ value and ${ }^{87} \mathrm{Sr} r{ }^{86} \mathrm{Sr}$ ratios for the $1.33 \mathrm{Ga}$ reference age (see Table 5). However, some samples of the late- to posttectonic plutons (PF0501, PRV0504, CP30507) indicated spurious ${ }^{87} \mathrm{Sr} r{ }^{86} \mathrm{Sr}_{\mathrm{t}}$ reference values $(<0.701)$ and were not further considered herein because the clear disturbance of their isotopic systems.

The correlation diagram discriminates different isotopic fields for the PCG rocks. The syn- to late-kinematic La Junta and San Martín samples yield ${ }^{87} \mathrm{Sr}^{86} \mathrm{Sr}_{\mathrm{t}}$ ratios from 0.704 to 0.706 , show predominantly negative $\varepsilon_{\mathrm{Nd}(t)}$ values (up to -4.3), and plot close to Bulk Earth. This reinforces the role of heterogeneous sources in their origin in an arc setting. The late- to post-kinematic plutons show two distinct signatures, combined a larger variation in ${ }^{87} \mathrm{Sr}^{2}{ }^{86} \mathrm{Sr}_{\mathrm{t}}$ ratios (from 0.702 to 0.707 ). The first group exhibits ${ }^{87} \mathrm{Sr}^{1 / 86} \mathrm{Sr}_{\mathrm{t}}$ ratios from 0.702 to 0.707 and $\varepsilon_{\mathrm{Nd}(1.33 \mathrm{Ga})}$ values from +1.48 to +2.75 . The second group (Diamantina) shows ${ }^{87} \mathrm{Sr}^{86} \mathrm{Sr}_{\mathrm{t}}$ values from 0.702 to 0.704 , and $\varepsilon_{\mathrm{Nd}(1.33 \mathrm{Ga})}$ values from +0.39 to -1.25 (Figure 12, Tables 4 and 5). The San Cristobal and Diamantina (CP0505) samples preserve the most juvenile signatures among the investigated PGC rocks. The signature implies again to the important role of Mesoproterozoic mantle sources in the petrogenesis, in agreement with an intra-oceanic arc setting.

The fact that these late- to post-kinematic intrusions are sharply discordant in relation with the regional foliation of the country rocks, in conjunction with their distinct positive $\varepsilon_{\mathrm{Nd}(t)}$ values and youngest $\mathrm{T}_{\mathrm{DM}}$ model ages suggest that they are products from a juvenile magmatic arc. In contrast, the syn- to late-kinematic granitoid rocks (e.g., La Junta granite) have Nd isotopic signatures that are coherent with mixing sources, except for the San Martín pluton.

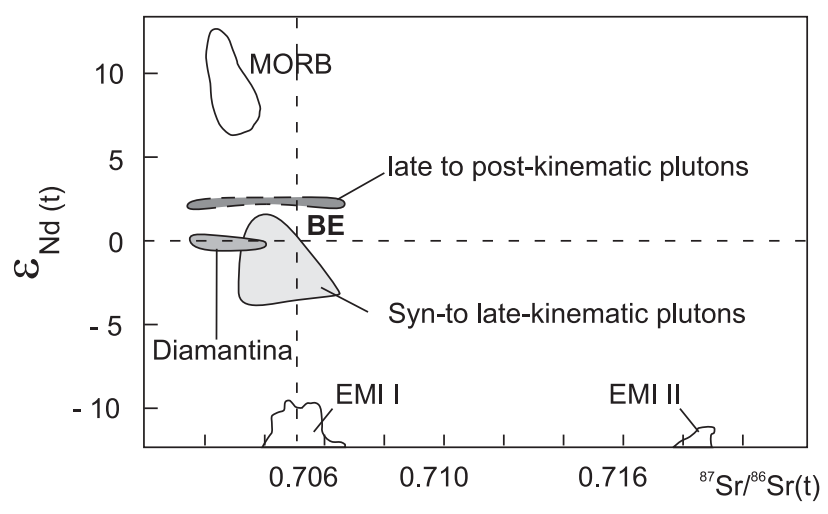

Figure 12. $\left({ }^{87} \mathrm{Sr} /{ }^{86} \mathrm{Sr}\right)_{(1.33 \mathrm{Ga})}$ VS. $\varepsilon_{\mathrm{Nd}(1.33 \mathrm{Ga})}$ correlation diagram for PG C samples. Symbols as shown in Figure 3. 


\section{DISCUSSION AND TECTONIC CORRELATION}

The PGC is formed by voluminous Mesoproterozoic syn- to late-kinematic and late- to post-kinematic granitoid events, dated between 1373 and $1340 \mathrm{Ma}$, as the SHRIMP $\mathrm{U}-\mathrm{Pb}$ evidence. Additional SHRIMP U-Pb zircon datings [Matos, in preparation (2009)] carried out in the La Junta and the Diamantina granites yielded comparable ages (1347 $\pm 21 \mathrm{Ma}$ and $1340 \pm 20 \mathrm{Ma}$, respectively), in agreement with a previous $\mathrm{Rb} / \mathrm{Sr}$ isochron age for the Diamantina pluton (Litherland et al., 1986) - whereas the San Martín Granite yielded a significantly older SHRIMP zircon age (1373 \pm $20 \mathrm{Ma}$ ). As such the geochronologic work provides new insights for the timing of the syn- to late tectonic phases of the San Ignacio Orogeny, in Bolivia. It is noteworthy that additional SHRIMP U-Pb zircon ages (Boger et al., 2005; Santos et al., 2006, 2008) for the basement rocks (Lomas Maneches and Chiquitania units) in the range $1.34-1.32 \mathrm{Ga}$ revealed metamorphic overprints associated with the San Ignacio Orogeny and also with coeval magmatic and deformational events in the Brazilian counterpart.

The PGC rocks display Nd-Sr ${ }_{(\mathrm{t})}$ signatures that suggest that different sources contributed to the magma genesis of the plutonic pulses, in coherence with the trace element compositions that reflect magmatic differentiation processes combined with crustal contamination (see above). This scenario is consistent with the onset of successive magmatic arcs culminating with continental collision of the PGC (at ca. $1.33 \mathrm{Ga}$ ) against the Rio Negro-Juruena Province, as proposed for the Mesoproterozoic evolution of the SW Amazonian craton (e.g., Boger et al., 2005; Cordani and Teixeira, 2007).

The syn- to late-kinematic La Junta granite has ${ }^{87} \mathrm{Sr} /{ }^{86} \mathrm{Sr}_{t}$ ratios of 0.704 to 0.706 , the oldest $\mathrm{T}_{\mathrm{DM}}$ ages $(1.9-2.0 \mathrm{Ga})$ and negative $\varepsilon_{\mathrm{Ndt}}$ values $(-2.9$ to -4.3$)$, as previously delineated by Darbyshire (2000). Such isotopic features favor again the hypothesis of significant contribution of crustal material in the petrogenetic process, supported by the recognized negative $\mathrm{Nb}$ and $\mathrm{Ta}$ anomalies in the studied samples, as well as by the plot of the samples near the boundary "within plate-volcanic arc granite fields" in the Pearce' Diagram (Figure 13). Furthermore, the syn- to late-kinematic plutons are associated with gneisses and migmatites, but do not contain basic xenoliths (Hawkins, 1982; Litherland, 1981; this work). This suggests that they are products from partial melting of the lower crust, as discussed by Nardi and Bonin (1991) on the basis of petrogenetic inferences from Proterozoic granites in southern Brazil.

The late- to post-kinematic Porvenir, San Cristobal, Piso Firme intrusions displayed $\varepsilon_{\mathrm{Ndt}}$ values from +2.7 to $+1.5 ; \mathrm{T}_{\mathrm{DM}}$ ages from 1.6 to $1.7 \mathrm{Ga}$, and ${ }^{87} \mathrm{Sr} /{ }^{86} \mathrm{Sr}_{t}$ ratios between 0.702 and 0.706. In addition, Darbyshire (2000) reported signifi- cant positive $\varepsilon_{\mathrm{Ndt}}$ values of +3.3 and +3.9 for the Piso Firme granophyre with $\mathrm{T}_{\mathrm{DM}}$ ages of 1.5 and $1.6 \mathrm{Ga}$. The isotopic signatures agree well with the observed $\mathrm{Sr}, \mathrm{P}$ and Ti negative peaks that are characteristics of fractional crystallization. This process is similarly envisaged from the presence of intermediate compositions of the late- to post-kinematic rocks (quartz monzonites to quartz syenites and syenogranites). The lower alkaline contents $\left(\mathrm{Na}_{2} \mathrm{O}+\mathrm{K}_{2} \mathrm{O}<8.5\right)$ are otherwise commonly seen in mantle derived rocks of arc settings. In the Pearce' diagram (Figure 13) the late- to post-kinematic samples fall in the within plate field (Porvenir, San Cristobal, Piso Firme). In contrast the Diamantina samples plot mainly within the "volcanic arc field" whereas they show ${ }^{87} \mathrm{Sr} /{ }^{86} \mathrm{Sr}_{t}(0.702$ to 0.704$)$ and $\varepsilon_{\text {Ndt }}$ values ( +0.4 to -1.2$)$ close to Bulk Earth (Figure 12). From the above signatures these plutons probably derived from mixtures among MORB-like magmas and isotopically homogeneous protholiths.

Petrogenetic models to explain the generation of felsic magmas, as the case of PGC, may be considered into two broad categories (Riley et al., 2001). The first assumption advocates that felsic magmas are derived from mafic parent magma by fractional crystallization or assimilation combined with fractional crystallization (AFC). This process is often suggested for small magma batches for generating large volumes of felsic magma, when unreasonably large amounts of basalt must be crystallized. Nevertheless, an alternative model, in which mafic magmas provide heat for the partial melting of crustal rocks, is considered more appropriate for large volume felsic magma bodies, likewise the case of the PGC.

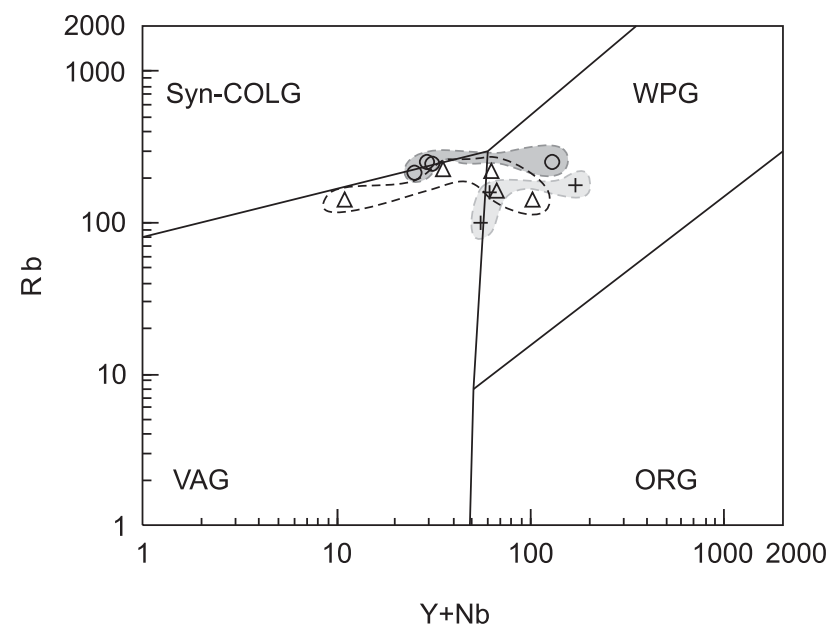

Figure 13. The $\mathrm{Rb}$ vs. $(\mathrm{Y}+\mathrm{Nb})$ discrimination diagram for PGC granites (after Pearce et al., 1984) showing the fields of syn-collisional granites (syn-CO LG ), within-plate granites (WPG), volcanic-arc granites (VAG) and ocean-ridge granites (O RG ). Symbols as shown in Figure 3. 
From the above, the integrated geological, geochemical and isotopic data suggest that the La Junta plutons (syn- to late-kinematic) resemble I-Caledonian type granites (e.g., Pitcher, 1993; Cobbing, 1996; Barbarin, 1999; Roberts and Clemens, 1993), which are represented by batholiths related to infracrustal melts linked with subduction of oceanic lithosphere beneath the more stable foreland. In contrast, most of the investigated late- to post-kinematic rocks originated predominantly from juvenile sources as suggested by the $\mathrm{Nd} / \mathrm{Sr}_{(\mathrm{t})}$ signatures, geochemistry and the observed primary hornblende. According to Chappell and White (2001) I-type suites range from metaluminous, hornblende-bearing granites to very weakly peraluminous rocks that contain biotite as the only ferromagnesian mineral.

The rocks of the PGC display roughly similar geochemistry to the Colorado Complex that occurs in the Brazilian counterpart. Major and trace elements data in PGC samples (Litherland et al., 1986) display regular trends of decreasing $\mathrm{Al}_{2} \mathrm{O}_{3}, \mathrm{MgO}, \mathrm{CaO}$ and $\mathrm{Fe}_{2} \mathrm{O}_{3 \text { Tot }}$ with increasing $\mathrm{SiO}_{2}$ contents. They are similarly sub-alkaline to high-K calc-alkaline, and metaluminous to peraluminous in composition. A similar chemical tendency is displayed by the contemporary syn-kinematic Igarapé Enganado Intrusive Suite, and the post-kinematic Alto Escondido Intrusive Suite of the Colorado Complex, in Rondônia, Brazil (Rizzotto and Quadros, 2007). On the other hand, the Diamantina granite shows high LREE fractionation pattern, and subhorizontal tendency of HREE with negative Eu anomalies which is similarly seen again by the granitoid suites of the Colorado Complex.

The Nd isotopic features of the Colorado felsic-mafic intrusions (Teixeira et al., 2006; Rizzotto and Quadros, 2007) - $\mathrm{T}_{\mathrm{DM}}$ model ages between 1.5 to $1.6 \mathrm{Ga}$ and $\varepsilon_{\mathrm{Nd}(\mathrm{t})}=+2.3-$ compares well with that of the San Martín and Piso Firme plutons; they are distinct from the La Junta isotopic features (see above). However, such a petrogenetic complexity may be expected in accretionary belts, in agreement with the tectonic framework of SW Amazonian Craton. In this respect, the late- to post-kinematic granitoids, including the Diamantina granite indicate juvenile- and crustal-like Nd signatures and show chemical features that are suggestive of differentiation from tonalites to alkali-feldspar granites. This strongly supports once more a plutonic arc setting for the origin of the Diamantina pluton in which a "fertilized" mantle source would be envisaged. If this is correct, the Porvenir, San Cristobal, Diamantina and Piso Firme granitoid rocks would display the most "primitive" signatures of such plutonic episodes among the PGC rocks investigated here. Furthermore, these late- to post- kinematic granitoid are comparable in age with the Alto Candeias Intrusive Suite (U-Pb ages of $1346 \mathrm{Ma}$ and $1338 \mathrm{Ma}$ ) in Rondônia (Bettencourt et al., 1999; Payolla et al., 2002). Moreover, the PGC granitoid rocks present negative values of $\mathrm{Nb}, \mathrm{Sr}$ and $\mathrm{Ti}$ whereas they show $\mathrm{Rb}, \mathrm{Ba}$ and $\mathrm{Th}$ enriched relative to $\mathrm{Nb}$ (Litherland et al., 1986). This is again a typical feature of magmas evolved in magmatic arcs.

Finally, according with the scenario for collisional orogenies envisaged by Condie (1997) we suggest that the PGC resulted from island arc evolution with the intervening Paraguá Craton, and further collision with the Rio Negro-Juruena Province. If this is true, the PGC rocks together with coeval igneous suites (e.g., Colorado Complex, Alto Candeias Intrusive Suite) represents the onset of the ultimate stage of the Rondonian-San Ignacio orogeny (Cordani and Teixeira, 2007), considered here as the major magmatic and metamorphic event that gave rise to the Rondonian-San Ignacio province.

\section{ACKNOWLEDGEMENTS}

Ramiro Matos thanks to CAPES (Coordenação de Aperfeiçoamento de Pessoal de Nível Superior) for the financial support for his Phd project. Wilson Teixeira, Mauro C. Geraldes and Jorge S. Bettencourt greatly acknowledge the support of CNPq (Conselho Nacional de Desenvolvimento Científico e Tecnológico, Brazil; grant \# 470373/2004-0). We sincerely thank to the reviewers for their suggestions that greatly improved the early version of the manuscript.

\section{REFERENCES}

BARBARIN, B. A review of the relationships between granitoid types, their origins and their geodynamic environments. Lithos, v. 46, p. 605-626, 1999.

BETTENCOURT, J. S.; TOSDAL, R. M.; LEITE, W. B. JR.; PAYOLLA, B. L. Mesoproterozoic rapakivi granites of the Rondônia Tin Province, southwestern border of the Amazonian craton, Brazil-I. Reconnaisance U-Pb geochronology and regional implications. Precambrian Research, v. 95, n. 1-2, p. 41-67, 1999.

BOGER, S. D.; RAETZ, M.; GILES, D.; ETCHART, E.; FANNING, M. C. U-Pb age data from the Sunsás region of Eastern Bolivia, evidence for the allochtonous origin of the Paraguá Block. Precambrian Research, v. 139, p. 121-146, 2005.

COBBING, J. Granites- an overview. Episodes, v. 19, n. 4, p. 103-106, 1996.

CONDIE, K. C. Plate tectonics and crustal evolution. 4. th ed. Butterworth: Oxford. 1997. 282 p. 
CORDANI, U. G.; SATO, K.; TEIXEIRA, W.; TASSINARI, C. C. G.; BASEI, M. A. S. Crustal evolution of the South American Platform. In: INTERNATIONAL GEOLOGIC CONGRESS, 31., 2000. Rio de Janeiro. Tectonic evolution of South America... Rio de Janeiro, 2000. p. 19-40.

CORDANI, U. G.; TEIXEIRA, W. Proterozoic accretionary belts of the Amazonian Craton. In: HATCHER, R.D. Jr., CARLSON, M. P., MCBRIDE, J. H. ; MARTINEZ CATALÁN, J. R. (Org.). The 4D Framework of Continental Crust. Boulder, Colo.: Geological Society of America, 2007. p. 297-320. (Memoir. v. 200).

CHAPPELL, B.W.; WHITE, A.J.R. Two contrasting granite types: 25 years later. Australian Journal of Earth Sciences, v. 48, p. 489-499, 2001.

DARBYSHIRE, D. P. F. The Precambrian of Eastern Bolivia - a Sm-Nd isotope study. In: INTERNATIONAL GEOLOGIC CONGRESS, 31., 2000, Rio de Janeiro. Abstract Volume ...Rio de Janeiro: CPRM , 2000. 1 CD-ROM.

DEPAOLO, D. J. A neodymium and strontium isotopic study of Mesozoic calc-alkaline granitic batholiths of of the Sierra Nevada and Peninsular Ranges, California. Journal Geophysical Research, v. 86, n B11, p. 10470-10488, 1981.

FITCH, F. J. Macro point counting. The American Mineralogist, v. 44, p. 667-669, 1959.

GERALDES, M. C.; VAN SCHMUS, W. R.; CONDIE, K. C.; BELL, S.; TEIXEIRA, W.; BABINSKI, M. Proterozoic geologic evolution of SW part of the Amazonian craton in Mato Grosso State, Brazil. Precambrian Research, v. 111, p. 91-128, 2001.

HAWKINS, M. P. The geology and mineral potential of the Manomó area (Part of quadrangle SD 20-16). Santa Cruz de la Sierra: British Geological Survey/Servicio Geológico de Bolivia, 1982. 105 p. (Informe, 13).

KLINCK, B. A.; O'CONNOR, E. A. The geology and mineral potential of the Perseverancia and Monte Verde areas (Quadrangles SD 20-15 and SD 20-11). Santa Cruz de la Sierra: British Geological Survey/Servicio Geológico de Bolivia, 1983. 178 p. (Informe, 11).

LE MAITRE, R. W. (Ed.). Igneous rocks: a classification and glossary terms. 2. ed. Cambridge: Cambridge University Press., 2002. 236 p.
LITHERLAND, M. The geology and mineral potential of the Huanchaca area (Parts of Quadrangles SD 20-15 and SD 20-11). Santa Cruz de la Sierra: British Geological Survey/Servicio Geológico de Bolivia, 1982. 173 p. (Informe, 10).

LITHERLAND, M.; BLOOMFIELD, K. The Proterozoic history of Eastern Bolivia. Precambrian Research, v. 15. p. 157-179, 1981.

LITHERLAND, M.; KLINCK, B. A. Introducing the terms "Paraguá Craton" and "Pensamiento Granitoid Complex" for use in sheet reports. Santa Cruz de la Sierra: British /Servicio Geológico de Bolivia, 1982. (Infor$\mathrm{me}, \mathrm{ML} / 37)$.

LITHERLAND, M.; ANNELLS, R. N.; APPLETON, J. D.; BERRRANGÉ, J. P.; BLOOMFIELD, K.; BURTON, C. C. I.; DARBYSHIRE, D. P. F.; FLETCHER, C. J. N.; HAWKINS. M. P.; KLINCK, B. A.; LLANOS, A.; MITCHELL, W. I.; O'CONNOR. E. A.; PITFIELD. P. E. J.; POWER, G.; WEBB, B. C. The geology and mineral resources of the Bolivian Precambrian Shield. Overseas Memoir/ British Geological Survey, London, v. 9, p. 1-153, 1986.

LITHERLAND. M.; ANNELLS, R. N.; DARBYSHIRE, D. P .F.; FLETCHER, C .J .N.; HAWKINS, M. P.; KLINCK, B. A.; MITCHELL, W. I.; O'CONNOR, E. A.; PITFIELD. P. E. J.; POWER, G.; WEBB, B. C. The Proterozoic of Eastern Bolivia and its relationship to the Andean mobile belt. Precambrian Research, v. 43, p. 157-174, 1989.

MATOS, R.; TEIXEIRA, W.; GERALDES, M. C.; CORDANI, U. G.; BETTENCOURT, J. S. U-Pb and Sm-Nd constraints to the evolution of Bolivian Precambrian terranes. (in preparation).

MANIAR, P. D.; PICOLLI, P. M. Tectonic discrimination of granitoids. Geological Society of America Bulletin, v. 101, p. 635-643, 1989.

MIDDLEMOST, E. A. K. Magmas and magmatic rocks. London: Longman, 1985. $352 \mathrm{p}$.

NARDI, L. V. S.; BONIN, B. Post-orogenic and nonorogenic alkaline granite associations:the saibro intrusive suite, southern Brazil- A case study. Chemical Geology, v. 92, p. 197-211, 1991.

NAVARRO, M. S. A implantação de rotina, e seu refinamento, para a determinação de elementos terras raras 
em materiais geológicos por ICP-OES e ICP-MS: aplicação ao caso dos granitóides de Piedade-Ibiúna (SP) e Cunhaporanga (PR). SP. 2004. 132 f. Dissertação (Mestrado) - Instituto de Geociências, Universidade de São Paulo, São Paulo.

PAYOLLA, B. L.; BETTENCOURT, J. S.; KOSUCH, M.; LEITE, W. B. JR.; FETTER, A. H.; VAN SCHMUS, W. R. Geological evolution of the basement rocks in the east-central part of the Rondônia Tin province, SW Amazonian craton, Brazil: $\mathrm{U}-\mathrm{Pb}$ and $\mathrm{Sm}-\mathrm{Nd}$ isotopic constraints. Precambrian Research, v. 119, p. 141-169. 2002.

PEARCE. J. A. ; HARRIS N. B. W.; TINDLE, A. G. Trace elements discrimination diagrams for the tectonic interpretation of granitic rocks. Journal of Petrology, v. 25 n. 4, p. 956-983, 1984.

PITCHER, W. S. The nature and origin of granite. New York: Blackie Academic and Professional, 1993. 321 p.

PITTFIELD, P. E. J. The geology and mineral potential of the Puerto Villazón area (Quadrangles SD 20-7 and SD 20-3). British Geological Survey/Servicio Geológico de Bolivia. Santa Cruz de la Sierra. 1983. 181 p. (Informe, 15).

RILEY, T. R.; LEAT, P. T.; PANKHURST, R. J.; HARRIS, C. Origin of large volume rhyolitic volcanism in the Antartic Peninsula and Patagonia by crustal melting. Journal of Petrology, v. 42, p. 1043-1065, 2001.

RIZZOTTO, G. J.; BETTENCOURT, J. S.; TEIXEIRA, W.; PACCA, I. I. G.; D'AGRELLA-FILHO, M. S.; VASCONCELOS, P.; BASEI, M. A. S.; ONOE, A.; PASSARELLI, C. R. Geologia e geocronologia da Suíte Metamórfica Colorado e suas encaixantes, SE Rondônia: implicações para a evolução Mesoproterozóica do SW do Craton Amazônico. Geologia USP. Série Científica, v. 2, p. 41-55, 2002.

RIZZOTTO, G. J.; QUADROS, M. L. E. S. Margem Passiva e Granitos Orogênicos do Ectasiano em Rondônia. In: SIMPÓSIO DE GEOLOGIA DA AMAZÔNIA, 10., 2007, Porto Velho. Anais eletrônico... Porto Velho: SBG-Núcleo Norte, 2007. 1 CD-ROM.

ROBERTS, M. P.; CLEMENS, J. D. Origin of high-potassium, calc-alkaline, I-type granitoids. Geology, v. 21, p. $825-828,1993$.

SADOWSKI, G. R.; BETTENCOURT, J. S. Mesoproterozoic tectonic correlations between eastern Laurentia and the western border of the Amazonian Craton. Precambrian Research, v. 76, p. 213-227, 1996.

SANTOS, J. O. S.; MCNAUGHTON, N. J.; MATOS, R.; HARTMANN, L. A.; POTTER, P. E.; FLETCHER, I. R., 2006. The Four Main Orogenies within the Autochthonous Mesoproterozoic Sunsás Province in SW Amazon Craton. In: CONGRESO GEOLÓGICO DE BOLIVIA, 17., 2006, Sucre: Resumenes...Sucre, 2006, p. 1-4.

SANTOS, J. O. S.; MCNAUGHTON, N. J.; HARTMANN, L. A.; FLETCHER, I. R.; MATOS, R. S. The age of deposition of the Aguapeí Group, western Amazonian Craton, based on $\mathrm{U}-\mathrm{Pb}$ study of diagenetic xenotime and detrital zircon. In: CONGRESO LATINOAMERICANO DE GEOLOGÍA, 12., 2005, Quito. Actas... Quito, 2005.

SANTOS, J. O. S.; RIZZOTTO, G. J.; MCNAUGHTON, N. J.; MATOS, R.; HARTMANN, L. A.; CHEMALE Jr., F.; POTTER, P. E.; QUADROS, M. L. E. S. Age and autochthonous evolution of the Sunsás Orogen in West Amazon Craton based on mapping and U-Pb geochronology. Precambrian Research, v. 165, p. 120-152, 2008.

SATO, K.; TASSINARI, C. C. G.; KAWASHITA, K.; PETRONHILO, L. O Método Geocronológico Sm-Nd no IGc/USP e suas aplicações. Anais da Academia Brasileira das Ciências, v. 67, p. 313-336, 1995.

SATO, K.; TASSINARI, C. C. G. Principais eventos de acreção continental no Cráton Amazônico baseados em idade modelo Sm-Nd, calculada em evoluçoes de estágio único e estágio duplo. In: COSTA, M.L.; ANGELICA, R.S., (Eds.). Contribuções à Geologia da Amazônia. Belém: Sociedade Brasileira de Geologia, 1997. p. 91-142.

SPARRENBERGER, I.; BETTENCOURT, J. S.; TOSDAL, R. M.; WOODEN, J. L. Datações U-Pb convencional versus SHRIMP do Maciço Estanifero Santa Bárbara, Suite Granitos Últimos de Rondônia, Brasil. Geologia USP. Série Científica, São Paulo, v. 2, p. 79-94, 2002.

STRECKEISEN, A. To each plutonic rock, its proper name. Earth Science Review, Amsterdam, v. 12, p. 1-33, 1976.

TAYLOR, S. R.; McLENNAN, S. M. The continental crust: its composition and evolution. Oxford: Blackwell Scientific Publications, 1985. 234 p.

TASSINARI, C. C. G.; BETTENCOURT, J. S.; GERALDES, M. C.; MACAMBIRA, M. J. B.; LAFON, J. 
M. The Amazon craton. In: INTERNATIONAL GEOLOGIC CONGRESS, 31., 2000, Rio de Janeiro. Tectonic evolution of South America... Rio de Janeiro, 2000. p. 41-95.

TEIXEIRA, W.; TASSINARI, C. C. G.; CORDANI, U. G.; KAWASHITA, K. A review of the geochronology of the Amazonian Craton: tectonic implications. Precambrian Research, v. 42, p. 213-227. 1989.

TEIXEIRA, W.; BETTENCOURT, J. S.; GIRARDI, V. A. V.; ONOE, A.; SATO, K.; RIZZOTTO, G. J. Mesoproterozoic mantle heterogeneity in the SW Amazonian Craton: ${ }^{40} \mathrm{Ar} /{ }^{39} \mathrm{Ar}$ and Nd-Sr isotopic evidence from mafic- felsic rocks. In: HANSKI, E.; MERTANEN, S.; RÄMÖ, T.; VUOLLO, J.(Eds). Dyke swarms - Time Markers of Crustal Evolution. London: Taylor \& Francis, 2006. p. 113-130.

TEIXEIRA, W., CORDANI, U. G. Proterozoic evolution of the Amazonian Craton reviewed. Special volume of the Indian Conference on Global Scenario. World Scientific. 2009 (in press).

TOHVER, E.; VAN DER PLUIJM, B. A.; VAN DER VOO, R.; RIZZOTTO, G.; SCANDOLARA, J. E. Paleogeography of the Amazon Craton at $1.2 \mathrm{Ga}$ : early Grenvillian collision with the Llano segment of Laurentia. Earth Planetary Sciences Letters, v. 199, p. 185-200, 2002.

TOHVER, E.; BETTENCOURT, J. S.; TOSDAL, R.; MEZGER, K.; LEITE. W. B.; PAYOLLA, B. L. Terrane transfer during the Grenville orogeny: tracing the Amazonian ancestry of southern Appalachian basement through $\mathrm{Pb}$ and $\mathrm{Nd}$ isotopes. Earth Planetary Science Letters, v. 228, p. 161-176, 2004a.

TOHVER, E.; VAN DER PLUIJM, B. A.; MEZGER, K.; ESSENE, E.; SCANDOLARA, J. E. Significance of the Nova Brasilândia metasedimentary belt in Western Brazil: redefining the mesoproterozoic boundary of the Amazon Craton. Tectonics, v. 23, TC6004, 2004b. doi: 10.1029/2003TC001563.

TOHVER, E.; VAN DER PLUIJM, B. A.; MEZGER, K.; SCANDOLARA, J. E.; ESSENE, E. Two stage history of the SW Amazon Craton in the late Mesoproterozoic: identifying a cryptic suture zone. Precambrian Research, v. 137 , p. $35-59,2005$ a.

TOHVER, E.; VAN DER PLUIJM, B. A.; SCANDOLARA, J. E.; ESSENE, E. Late Mesoproterozoic deformation of SW Amazonia (Rondônia, Brazil): geochronolog- ical and structural evidence for collision with southem Laurentia. Geology, v. 113, p. 309-324, 2005 b.

TOHVER, E.; TEIXEIRA, W.; VAN DER PLUIJM, B. A.; GERALDES, M. C.; BETTENCOURT, J. S.; RIZZOTTO, G. Restored transect across the exhumed Grenville orogen of Laurentia and Amazonia, with implications for crustal architecture. Geology, v. 34, p. 669-672, 2006. 
Appendix A. Petrographic description of the Pensamiento G ranitoids Complex rocks.

\begin{tabular}{|c|c|c|}
\hline Sample & Pluton & Main characteristics \\
\hline PF0501 & Piso Firme & $\begin{array}{l}\text { Medium-fine grained, pinkish brown, massive porphyry quartz syenite. The thin section } \\
\text { shows intergrowth of quartz and alkali feldspar of micrographic type and radiate fabric. } \\
\text { Subordinate anhedral quartz occurs as clusters together with isolated laths of plagioclase } \\
\text { or aggregates. Muscovite appears as scarce secondary mineral. Ferromagnesian } \\
\text { minerals were not observed. }\end{array}$ \\
\hline SC10502 & San Cristobal & $\begin{array}{l}\text { Pink medium-grained, slightly foliated monzogranite gneiss. It shows inequigranular } \\
\text { anhedral texture. It contains clusters of anhedral quartz. The K-feldspar and plagioclase } \\
\text { show variable sizes. The plagioclase (An26) and feldspar crystals form cloudy sericitised } \\
\text { surfaces. }\end{array}$ \\
\hline SC20503 & San Cristobal & $\begin{array}{l}\text { Medium-fine grained, pinkish white, banded monzogranite gneiss with small and } \\
\text { discontinuous streaky biotite. It is common an anhedral inequigranular texture. Clusters } \\
\text { of quartz are of different sizes. The microcline appears in subhedral crystal tablets. } \\
\text { Plagioclase (An27) in small crystals appears between quartz and feldspar. The biotite is } \\
\text { pale straw-yellow to dark olive-green. The spheneis principal accessory mineral. }\end{array}$ \\
\hline PRV0504 & Porvenir & $\begin{array}{l}\text { Medium-fine grained, pinkish massive syenogranite. It has an inequigranular anhedral } \\
\text { seriate texture. A granular mixture of quartz and feldspar appears with few crystals } \\
\text { of hornblende and biotite. The K-feldspar shows microcline-type twinning and forms } \\
\text { anhedral K-microperthite. Plagioclase (An29) shows albite twins, and some clusters } \\
\text { of anhedral quartz are also present. The biotite is straw yellow to pale redish brown. } \\
\text { The hornblende is green and appears as clusters associated with biotite and irregular } \\
\text { masses of opaque minerals. }\end{array}$ \\
\hline СР0505 & Diamantina & $\begin{array}{l}\text { Coarse to medium- grained, pinkish white, massive to slightly porphyritic syenogranite. } \\
\text { It shows equigranular anhedral to subhedral texture. The K-feldspar is microperthite } \\
\text { and shows microcline-type twinning. Some orthoclase crystals show Carlsbad twinning. } \\
\text { Scarce patches of plagioclase are intergrowth with vermicular quartz. Some plagioclase } \\
\text { crystals (An26) contain shreds of muscovite. The biotite is pale straw-yellow to dark } \\
\text { olive-green, and scarcely chloritized. Irregular mass of opaque minerals are also } \\
\text { present. Euhedral zircon and scarce apatite may form biotite inclusions. }\end{array}$ \\
\hline CP20506 & Diamantina & $\begin{array}{l}\text { Medium grained, white, massive to slightly porphyritic syenogranite. It has a consistently } \\
\text { equigranular subhedral to anhedral texture. The plagioclase crystals (An28) contain } \\
\text { a dense mass of very fine grained muscovite and clay minerals of brown pale color } \\
\text { ascribed to alteration. The K-feldspar, a well developed microperthite, shows microcline- } \\
\text { type twinning. The biotite is a pale straw-yellow to dark olive-green, sometimes } \\
\text { chloritized. Secondary epidote occurs in small crystals. Squeletal masses of opaque } \\
\text { minerals contain apatite and epidote. Zircon and apatite in euhedral crystals are the } \\
\text { common accessory minerals. }\end{array}$ \\
\hline CP30507 & Diamantina & $\begin{array}{l}\text { Medium grained, white, massive to slightly porphyritic syenogranite. The thin section } \\
\text { shows an inequigranular anhedral texture. The K-feldspar is a usually a microcline- } \\
\text { microperthite, and the scarce orthoclase-microperthite shows Carlsbad-type twinning. } \\
\text { Patches of plagioclase are seen as intergrowth with vermicular quartz. The biotite is } \\
\text { pale straw-yellow to dark olive-green. Shred muscovite is seen in plagioclase. Irregular } \\
\text { masses of opaque minerals are associated to biotite. The principal accessory mineral } \\
\text { is euhedral apatite. }\end{array}$ \\
\hline
\end{tabular}


Appendix A. (continued)

\begin{tabular}{|c|c|c|}
\hline Sample & Pluton & Main characteristics \\
\hline ME0508 & Diamantina & $\begin{array}{l}\text { Pinkish white, medium-coarse grained quartz monzonite with an equigranular subhedral } \\
\text { to anhedral texture. It contains some phenocrysts of K-feldspar microperthite that show } \\
\text { microcline-type twinning. The plagioclase crystals contain very fine grained muscovite } \\
\text { and clay minerals of brown pale color. Abundant patches of plagioclase are intergrown } \\
\text { with vermicular quartz. Biotite is pale straw-yellow to dark olive-green. Few minute } \\
\text { secondary epidote is also present. Euhedral apatite and zircon inclusions occur as } \\
\text { inclusions in the biotite. }\end{array}$ \\
\hline CA0509 & San Martín & $\begin{array}{l}\text { Medium-fine grained, banded and foliated pink syenogranite gneiss with euhedral } \\
\text { hornblende with inequigranular anhedral texture. Broad sinuous, albite lamellae } \\
\text { traverses the tartan twinning of a microcline crystal. Small plagioclase crystals contain } \\
\text { very fine muscovite and clay minerals. Common clusters of anhedral quartz with wavy } \\
\text { extinction are also present, and secondary quartz in fine aggregates form some mosaics. } \\
\text { Irregular mass of opaque minerals and minute crystals of secondary epidote are also } \\
\text { present. Pale to dark brown allanite appears in aggregates of few crystals. }\end{array}$ \\
\hline FLT0510 & La Junta & $\begin{array}{l}\text { Coarse-grained syenogranite gneiss, pink in color with inequigranular anhedral texture. } \\
\text { Microperthitic intergrowth shows narrow albite lamellae forming a braided pattern in } \\
\text { an orthoclase host. Small plagioclase crystals contain very fine muscovite and clay } \\
\text { minerals of brown pale color in parallel polarized light. Plagioclase occurs as deformed } \\
\text { twins. Streaky banded chloritized biotite is associated with epidote aggregates, sphene } \\
\text { and irregular redish opaque minerals occurs as intergrowths with vermicular quartz. } \\
\text { Sphene shows a micrographic intergrowth. Euhedral apatite is also present. }\end{array}$ \\
\hline LJ10511 & La Junta & $\begin{array}{l}\text { Coarse grained, pinkish white, massive to slightly foliated and porphyritic quartz } \\
\text { monzonite with an inequigranular anhedral texture. Microcline microperthitic intergrowth } \\
\text { is common as well as some clusters of anhedral quartz. Abundant patches of plagioclase } \\
\text { occurs as intergrowths with vermicular quartz. The plagioclase contains very fine } \\
\text { muscovite and brown pale clay minerals in parallel polarized light. The biotite is a pale } \\
\text { straw-yellow to greenish brown mineral and is chloritized. }\end{array}$ \\
\hline LJ20512 & La Junta & $\begin{array}{l}\text { Medium grained, pinkish white, porphyritic monzogranite with an inequigranular } \\
\text { subhedral to anhedral texture. It contains granular cluster of quartz of different size, } \\
\text { with sutured contacts. The K-feldspar shows microcline-type twinning. The anhedral } \\
\text { plagioclase contains very fine muscovite and clay minerals of brown pale color in } \\
\text { parallel polarized light. The plagioclase (An29) slows a pericline twinning, and the biotite } \\
\text { is a pale straw-yellow to dark olive-green poorly chloritized. Irregular masses of opaque } \\
\text { minerals are also present. The principal accessory mineral is the euhedral sphene. }\end{array}$ \\
\hline LJ30513 & La Junta & $\begin{array}{l}\text { Medium grained, gray pinkish monzogranite with an inequigranular anhedral to } \\
\text { subhedral texture. The K-feldspar is microperthite and shows microcline-type twinning. } \\
\text { The plagioclase contains a fine shred of muscovite, and contains patches of vermicular } \\
\text { quartz. The hornblende is pleochroic, and in shades of green. Biotite is pale straw- } \\
\text { yellow to dark olive-green, sometimes with relict aspect between the crystals of quartz } \\
\text { and feldspars. Secondary epidote is rare. Apatite appears as euhedral crystal. }\end{array}$ \\
\hline
\end{tabular}


Appendix B. Summary of megascopic and microscopic petrography for the Pensamiento Granitoids Complex rocks (after Klinck and O 'Connor, 1983; Hawkins, 1982; Pitfield, 1983; Litherland, 1982).

\begin{tabular}{|c|c|}
\hline Pluton & Main characteristics \\
\hline $\begin{array}{l}\text { San Martin Granite (Klinck } \\
\text { and O'Connor, 1982). }\end{array}$ & $\begin{array}{l}\text { In the undeformed granite a xenomorphic interlobate equigranular texture is present; the color ranges } \\
\text { from greyish-orange-pink, greyish-pink, yellow-brown to light-olive brown. Modal analysis plot in the } \\
\text { monzogranite field. Equigranular more rarely inequigranular, locally hypidiomorphic texture is observed } \\
\text { with plagioclase forming equant grains. Quartz forms ameboid crystals and sutured interlobate mosaics. } \\
\text { The K-feldspar is usually microcline-microperthite. Tabular plagioclase (An26) insets with a clear rim and } \\
\text { sericitised core are common along with blob-like quartz inclusions. Biotite forms straw or olive brown } \\
\text { colored flakes and is associated with accessory opaque ore, zircon and apatite. Accessory epidote } \\
\text { appears in some samples in association with the biotite. } \\
\text { In the deformed granite three increments of deformation-intensity from quartz textures are seen. The } \\
\text { first comprises intergranular milonitisation between quartz grains with a precursor development of mortar } \\
\text { texture. The biotite fabric is still random. The second increment in intensity of deformation generated } \\
\text { xenoblastic, interlobate elongate textures. The biotite defines a tectonic fabric of variable intensity. The } \\
\text { quartz occurs as elongate lenses and is parallel to the biotite fabric. The quartz ribbon texture appears } \\
\text { and plagioclase twin planes are deformed as intensity of deformation increases. The ribbons define a } \\
\text { preferred orientation. Subsequent metamorphism caused partial polygonisation. } \\
\text { Xenoliths: banded migmatites (e.g., Chiquitania Complex). }\end{array}$ \\
\hline & $\begin{array}{l}\text { Pinkish-grey in color, medium-to coarse-grained, gneissic monzogranite to syenogranite which grades } \\
\text { into a paler pink variety with a lower biotite content. The rock consists of porphyroblastic alkali feldspar } \\
\text { and string perthitic microcline, aligned parallel to the biotite and associated to quartz and plagioclase } \\
\text { with myrmekitic intergrowth. The biotite appears altered to chlorite. The accessory minerals are: sphene } \\
\text { (locally altering to leucoxene), zircon, apatite, allanite and opaque ores. Some secondary calcite and } \\
\text { epidote may be present locally. } \\
\text { The La Junta Granite exhibits a well-developed migmatitic envelope along its southern margin that } \\
\text { suggests an autochtonous origin. } \\
\text { Xenoliths: partly absorbed rocks (hornblende-biotite gneiss, calc-silicate gneiss, quartzite, amphibolite). }\end{array}$ \\
\hline $\begin{array}{c}\text { Piso Firme Granophyre } \\
\text { (Pitfield, 1983). }\end{array}$ & 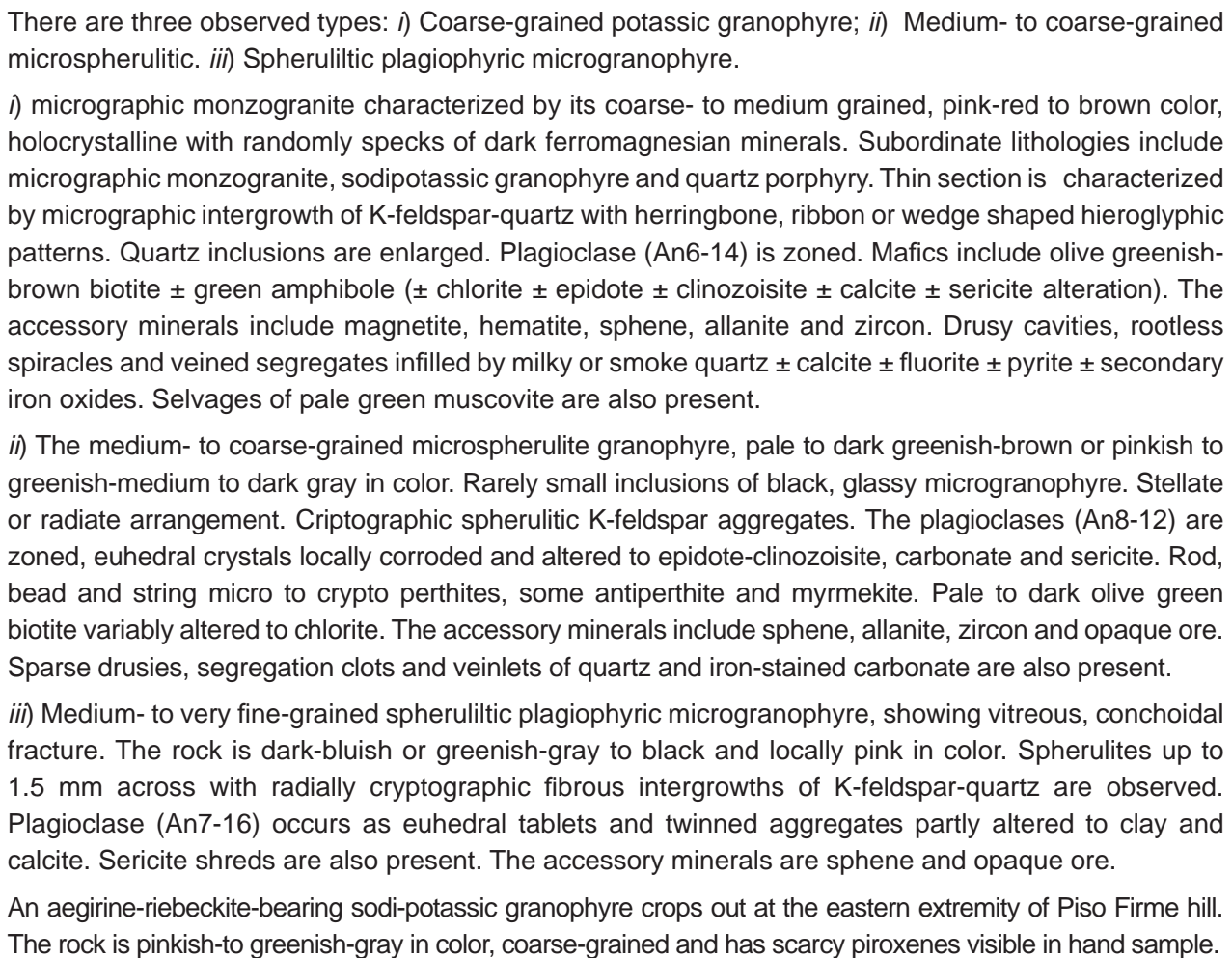 \\
\hline
\end{tabular}


Appendix B. (continued)

\begin{tabular}{|c|c|}
\hline Pluton & Main characteristics \\
\hline $\begin{array}{c}\text { The San Cristobal } \\
\text { Metagranite (Pitfield, } \\
\text { 1983). }\end{array}$ & $\begin{array}{l}\text { It is a medium-to coarse- or very coarse-grained, pink to pale pinkish-grey in color, variably foliated } \\
\text { hornblende-biotite adamellite. The normalised quartz-feldspar modal percentages are consistent with } \\
\text { a monzogranite composition. In thin section the metagranite shows a hypidiomorphic to xenomorphic } \\
\text { granular texture with more or less equal proportions of quartz, plagioclase and variably perthitic microcline. } \\
\text { It rarely forms small augen and lensoid segregates. The quartz is clear to smoky in color and appears } \\
\text { streaked or elongated with the foliation. The K-feldspar forms incipient blastic growths enveloping other } \\
\text { mineral phases and presents an anastomising habit. Plagioclase (An14-26) shows corrosion and } \\
\text { replacement by K-feldspar with local myrmekitic reaction fronts or globular quartz inclusions. Biotite } \\
\text { constitutes up to } 5 \% \text { of the rock, forming pale to dark olive green flakes which define a foliation. Bright } \\
\text { green to dark blue-green, somewhat poikilitic hornblende, no more than } 2 \% \text { of the rock, is associated } \\
\text { with biotite in composite aggregates. Both biotite and hornblende may be altered to chlorite. The main } \\
\text { accessory minerals are sphene, zircon, magnetite and less commonly, metamict allanite. The sphene } \\
\text { occurs as scattered grains and lozenge-shaped sections as well as a mantling to some opaque minerals. } \\
\text { Zircon is typically zoned with idiomorphic overgrowths on rounded detrital grains. } \\
\text { Xenoliths: biotite-hornblende gneisses, biotite amphibolites and epidote calc-silicate rocks. }\end{array}$ \\
\hline $\begin{array}{c}\text { Porvenir Granite } \\
\text { (Klinck and O'Connor, } \\
\text { 1982) }\end{array}$ & $\begin{array}{l}\text { It consists of greyish-orange, pink to pale-red, medium-grained equigranular biotite-hornblende } \\
\text { monzogranite. A weak linear fabric is defined by the streaking of mafics and the preferred orientation } \\
\text { of the quartz-feldspathic groundmass. The texture is xenoblastic-interlobate, inequigranular. K-feldspar } \\
\text { microcline perthite occurs as xenoblastic grains with drop-like quartz inclusions. The plagioclase forms } \\
\text { cloudy sericitised grains in the groundmass and is also recrystallised into the granoblastic polygonal } \\
\text { varieties into the mosaic. The mafics are greenish-straw colored biotite and green hornblende that forms } \\
\text { clots with opaque ore. It can be associated with epidote and sphene. }\end{array}$ \\
\hline $\begin{array}{c}\text { Diamantina Granitoid } \\
\text { (Klinck and O'Connor, } \\
\text { 1982) }\end{array}$ & 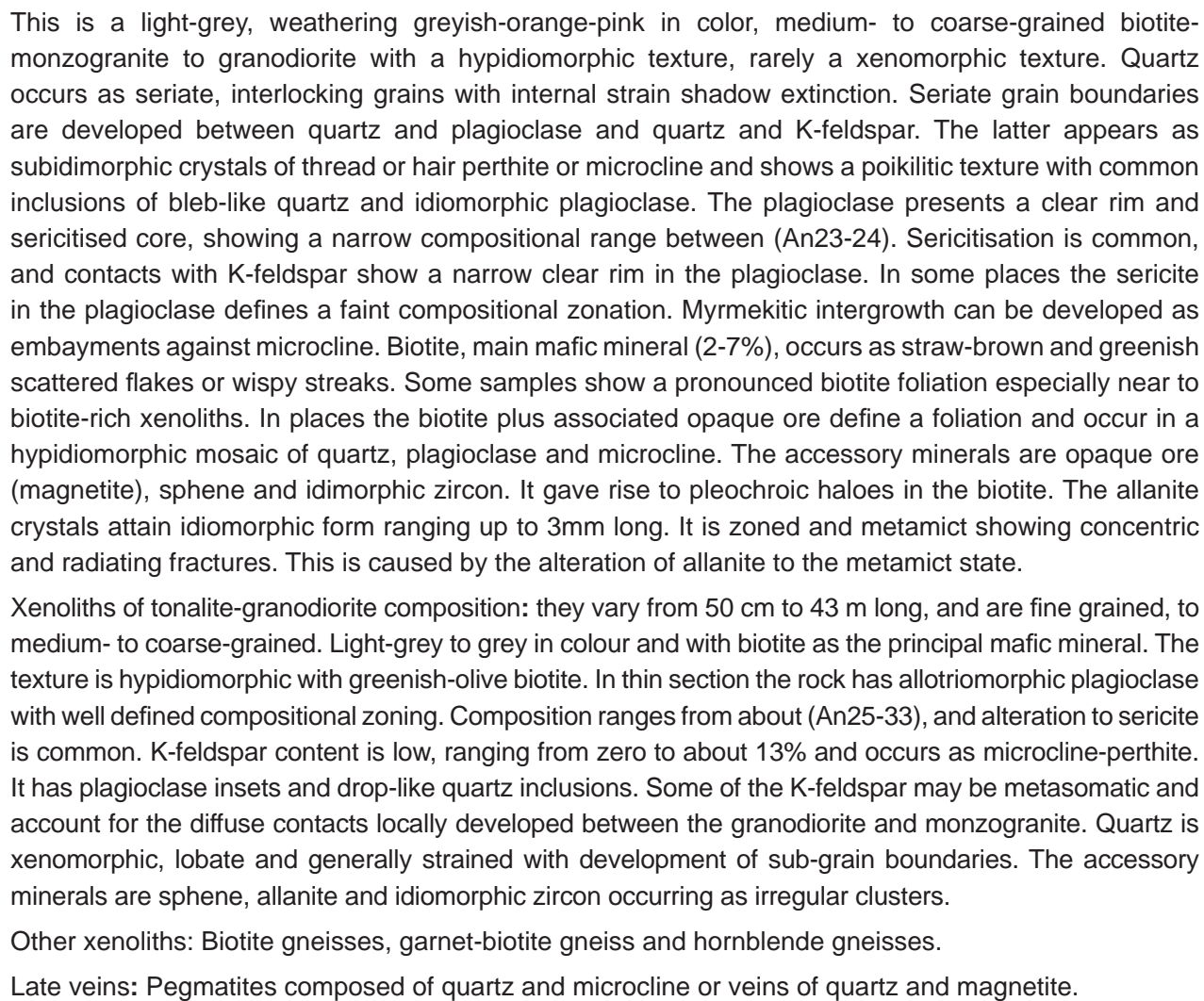 \\
\hline
\end{tabular}


Appendix B. (continued)

\begin{tabular}{|c|l|}
\hline Pluton & \multicolumn{1}{c|}{ Main characteristics } \\
\hline \multirow{5}{*}{$\begin{array}{c}\text { Diamantina Granitoid } \\
\text { (Litherland, 1982), }\end{array}$} & $\begin{array}{l}\text { In the eastern sector of the body occurs a pale pink or pale grey, medium-to medium-coarse-grained rock, } \\
\text { in places containing scattered K-feldspar megacrysts that ranges from } 1 \text { to } 3 \mathrm{~cm} \text { long. The investigated } \\
\text { samples were classified as quartz syenite to quartz-monzonite, and syenogranites and monzogranites } \\
\text { in composition. }\end{array}$ \\
$\begin{array}{c}\text { Microcline or perthite megacrysts enclose smaller crystals of altered plagioclase and quartz. The } \\
\text { plagioclase may be zoned and variable altered to sericite or epidote. The accessory minerals are: } \\
\text { apatite, ore, zircon and allanite whose crystals up may be to } 3 \mathrm{~mm} \text { long. } \\
\text { The southern part of the body is migmatitic with paleosome (gneiss) and neosome (granitoid) } \\
\text { components mixed on all scales. Small pegmatitic veins and segregations of approximately } 5 \mathrm{~cm} \text { thick } \\
\text { may be present. } \\
\text { Xenoliths: biotite-rich schists or biotite gneisses, that are up to } 5 \mathrm{~m} \text { long. }\end{array}$ \\
\hline
\end{tabular}


